\title{
MAKING CHAMPERTY WORK: AN INVITATION TO STATE ACTION
}

\author{
PAUL BOND
}

\section{INTRODUCTION}

Generically, the doctrine of champerty prohibits the sale of the fruit of legal judgment or settlement, in advance of such judgment or settlement, to an otherwise disinterested party. ' Contemporary scholarship tends to assert that the doctrine is vestigial and on the wane. ${ }^{2}$ In pursuit of efficiency and justice in litigation funding, many propose an outright repudiation of the prohibition against champerty. ${ }^{8}$ The result of such

${ }^{\dagger}$ B.A. 1997, Drew University; J.D. Candidate 2002, University of Pennsylvania. Special thanks to my wife, Wendy, and to my parents, Thomas and Suzanne. My gratitude to those who edited this Comment, including Courtney Breen, Garret Broadrup, Lindsay Goldman, and Michal Marcus. For their encouragement, advice, and example, I thank Penn Professors Seth Kreimer, Curtis Reitz, and Catherine Struve. Lastly, I thank Wade Berrettini, Alexandra McLean, and Joseph Wright for their invaluable assistance during the authorship of this Comment.

1 This definition is of the author's invention, but it seems best to fit the bulk of the cases surveyed in the Appendix. The 1913 edition of Webster's Dictionary, the most recent version to which the author is inclined to give credence, defines champerty at law as " $[t]$ he prosecution or defense of a suit, whether by furnishing money or personal services, by one who has no legitimate concern therein, in consideration of an agreement that he shall receive, in the event of success, a share of the matter in suit." WEBSTER'S REVISED UNABRIDGED DictionaRY 238 (Noah Porter ed., 1913).

Webster's is a perfectly serviceable definition. The author's definition of champerty varies from Webster's because: (1) state law rarely prosecutes the funding of litigation defenses as champertous; (2) caselaw does not suggest that "money or personal services" should be treated with any more suspicion than the rest of the universe of valuable consideration; (3) one may have a "legitimate concern" for the outcome of a suit, ranging from simple human pity to complex economic entanglements, and yet not possess the standing necessary to appear before the court as a fellow plaintiff; and (4) "success" ought to be expanded explicitly to include settlements by which money flows to the assignees of the claim.

${ }^{2}$ See, e.g., Harold J. Krent, The Fee-Shifting Remedy: Panacea or Placebo?, 71 CHI.KENT L. REV. 415, 425-26 (1995) (citing a proposal that "would allow the market to sort out appropriate financing arrangements at the expense of vestigial champerty restrictions" (emphasis added)).

See, e.g., Susan Lorde Martin, Financing Plaintiffs' Lawsuits: An Increasingly Popular (and Legal) Business, 33 U. MiCH. J.L. REFORM 57, 83 (2000) ("Today a variety of mechanisms are available to discourage those evils [i.e., interference by noblemen and 
an outright repudiation would be a free market in future legal judgments.

This Comment suggests that champerty's critics underestimate the continuing vitality of the doctrine. Substantial justifications for the ancient prohibition still obtain. By examining the interests of groups most affected by changes in litigation funding, this Comment develops an alternative to suboptimal "champerty not allowed" and "champerty allowed" rules. This alternative, embodied in a proposed state Model Act of Champerty, ${ }^{4}$ simplifies the law, protects those now sheltered by the prohibition, and captures the economic and normative gains sought by proponents of liberalization.

Through a simple slip-and-fall case, Part I introduces champerty in action. A plaintiff needs money. An otherwise disinterested third party-a champertor-wants to invest in the suit. A deal is struck. Unexpectedly, the courts intervene. Part I unpacks the possible rationales the court may have for interfering, providing the vocabulary required for a meaningful discussion of champerty. Part II of this Comment argues that both the total prohibition of champerty and the complete liberalization of the field exact unpalatable social costs. Part III, laying out the proposed Model Act, suggests a more active, nuanced approach for state legislatures to take. Champerty is simply too important to be left to the champertors-the State should supervise the sale of legal claims and shape procedures to protect all interests at stake. Finally, Part IV considers and responds to the most likely objections to this pilot program. Appended to this Comment is a brief survey of the current state of champerty caselaw in all fifty states and the District of Columbia.

officials in litigation in medieval England, to oppress hapless defendants], making a ban on champerty completely unnecessary.").

${ }^{4}$ The Model Act of Champerty is the invention of this author. Attribution is given where elements of existing systems have been incorporated. Readers should pay attention not so much to the language of the statute but to the operation of the process it envisions. 


\section{CHAMPERTY, BRIEFLY}

\section{A. A Conventional Account}

A shopkeeper fails to de-ice the path into his store. As a result, customer Smith slips, falls, and breaks her back. Expecting that Smith will prevail in court, Jones offers her $\$ 10,000$ up front in exchange for whatever she wins at trial. Smith agrees. At trial, Smith is awarded $\$ 200,000$. She repudiates her written contract with Jones and gives him nothing. When Jones sues Smith for the $\$ 200,000$, the court holds that the contract at issue is unenforceable as contrary to the state statute, common law, and public policy against champerty. "In this jurisdiction," Jones is told, "the fruit of legal judgment or settlement cannot be sold in advance to a third party.",

For many causes of action, Jones could have purchased not only the future judgment, but also the right to bring the case to court. For example, Jones could have bought accounts receivable owed to Smith (factoring), or a now-broken contract that did not preclude assignment in its terms, or a quitclaim on property with a clouded title, or even, in many states, a tort claim not personal to Smith. ${ }^{8}$ On the basis of any of these assignments Jones could bring suit himself and personally receive the judgment. But "public policy still invalidates assignments of certain types of choses in action, including ... personal torts." These unassignable personal torts include those based on "assault and battery; personal injury; false imprisonment; malicious

${ }^{5}$ The intricacies of champerty's history, i.e., its evolution through seven hundred years of Anglo-American common law, are beyond the scope of this Comment. Readers interested in this subject are advised to see generally Max Radin, Maintenance by Champerty, 24 CAL. L. REV. 48 (1936).

${ }^{6}$ In most jurisdictions, Jones still could recover the $\$ 10,000$ he gave Smith in quantum meruit. See Arthur L. Kraut, Contingent Fee: Champerty or Champion?, CLEV. ST. L. REV., May 1972, at 15, 19 ("Even where the courts have declared a fee arrangement to be unenforceable by reason of champerty, the attorney has been able to recover in quantum meruit the reasonable value of the legal services he has rendered.").

${ }^{7}$ See 32 AM. JUR. 2D Factors and Commission Merchants $\$ 2$ (2000) (““[F]actoring' in modern commercial practice is understood to refer to the purchase of accounts receivable from a business by a 'factor' who thereby assumes the risk of loss in return for some agreed discount."). In general, factors are financiers providing clients (typically manufacturers or suppliers of goods) with working capital by purchasing their accounts receivable. Id.

${ }^{8}$ See 6 AM. JUR. 2D Assignments $\$ 51$ (1999) ("A chose in action is generally assignable, if it is the type of claim that would survive the death of the assignor and pass to his or her personal representative, and if there is no statutory or contractual provision prohibiting its assignment." (footnotes omitted)).

${ }^{9}$ Id. $\$ 53$ (footnotes omitted). 
prosecution; invasion of privacy; defamation; conspiracy to injure another's business; [and] unfair and deceptive trade practices."

In theory, champertous contracts could fund any sort of litigation. In practice, however, most contracts invalidated as champertous were drafted to fund tort litigation. " Only the liberalization of personal tort judgments is considered in this Comment. Some assignees are exempt ${ }^{12}$ and many end-runs around the prohibition have been suggested. ${ }^{19}$ But in most states champerty is banned, and champertous

${ }^{10} I d . \$ 64$ (footnotes omitted).

$"$ This Comment deals almost exclusively with "champerty" as a defense to the enforcement of contracts to fund litigation. See, e.g., Tosi v. Jones, 685 N.E.2d 580, 583 (Ohio Ct. App. 1996) ("[T]he doctrines of champerty and maintenance appear in numerous Ohio cases as contract defenses.").

All other uses of the term radiate from the illegality of these contracts. See id. (using "champerty" to mean a tort action available to the defendant in the funded suit, good against the parties to the illicit contract); see also ME. REV. STAT. ANN. tit. 17-A, $\$ 516(3)$ (West 1964) (making “champerty" a Class E crime under Maine law).

Sometimes assignments of things are held champertous because the new owner will have the right to sue for legal judgment. See, e.g., Johnson v. Sellers, 84 P.2d 744, 751 (Wyo. 1938) (hearing a claim that the purchase of land with the intent to bring suit should be voided as champertous).

The assignment of choses in action, i.e., the sale of the right to sue to a disinterested party, often has been disallowed as entailing the champertous sale of a legal judgment. See, e.g., Roberts v. Holland \& Hart, 857 P.2d 492, 495-96 (Colo. Ct. App. 1993) (prohibiting assignment of legal malpractice claims, in part because such assignment would "promote champerty"). But see, e.g., Charlotte-Mecklenburg Hosp. Auth. v. First of Ga. Ins. Co., 455 S.E.2d 655, 657 (N.C. 1995) (“[A]ssignment of a claim gives the assignee control of the claim and promotes champerty. Such a contract is against public policy and void. The assignment of the proceeds of a claim does not give the assignee control of the case and there is no reason it should not be valid." (citations omitted)).

${ }_{12}$ Often, a fellow real party in interest is exempt. See 14 AM. JuR. 2D Champerty and Maintenance $\$ 2$ (1999) ("A person who had a legally cognizable interest in the subject matter of a suit, prior to engaging in any conduct alleged to constitute champerty ... cannot be guilty of champerty . . . with respect to such suit." (footnotes omitted)). If both Smith and Jones had fallen on the icy walk, Smith could sell her portion of their claim against the shopkeeper to Jones.

Moreover, Smith can sell a portion of her claim to her attorney in the form of a contingency fee. Historically, the prohibition against champerty had blocked such fee agreements. See generally Peter Karsten, Enabling the Poor to Have Their Day in Court: The Sanctioning of Contingency Fee Contracts, a History to 1940, 47 DEPAUL L. REV. 231, 233 (1998) ("[C]ontingency fee arrangements were unavailable to a 'poor man' . . . in 1649.").

Ari Dobner ingeniously suggests that the modern prohibition against champerty can be circumvented through careful drafting. Since champerty is legal under the statutes, common law, and public policy of at least New Jersey, contractors in any other state simply need to draft their documents so that they will be construed under New Jersey law. See Ari Dobner, Litigation for Sale, 144 U. PA. L. REV. 1529, 1589 (1996) (arguing that by "execut[ing] the champertous agreements in New Jersey, includ[ing] 
assignments are unenforceable. Where allowed, champerty is authorized only by common law.

\section{B. Three Unconventional Distinctions}

This Comment distinguishes three forms of champerty: malice champerty, market champerty, and public champerty. ${ }^{14}$ Each fits within the genus of champerty defined above. Any close analysis, however, may hang on the often-neglected differences between these species of champerty.

Malice champerty is the funding of frivolous litigation by an otherwise disinterested party, with the purpose of harming or discomfiting the defendant. To the degree that the prohibition on champerty was directed towards this ill, it has been replaced largely by related doctrines, such as the tort of malicious prosecution and the contract defenses of unconscionability and duress.

I contend that the rule against champerty finds its modern justification in the danger of market champerty. That is, even meritorious suits, when made the object of unlimited funding, can cause harm in and through the courts. The current rule against champerty stops this harm only by stunting the market for future legal judgments.

Finally, I propose that the states have the power to harness all incentives toward champerty and turn them towards the common good. This still-theoretical process could be called public champerty. With public supervision, full-scale markets for legal judgments someday may become as beneficial and uncontroversial as any field of finance. This Comment suggests one bridge of laws that might be built toward that goal.

\section{WHO CARES ABOUT CHAMPERTY?}

Jurists have described the doctrine of champerty as "dated," 15 "an-

New Jersey choice-of-law and forum-selection clauses in the agreement, and bring[ing] the underlying champertous lawsuit in the real plaintiff's name," a contractor in any state can invest in litigation). "If these ... steps are taken, investing in litigation is possible and practicable in any state." Id.

Dobner is correct under the current system, but as I suggest in Part III, state legislatures can insist that it is against the public policy of the state to have litigationfunding contracts interpreted under the laws of any other state.

${ }^{14}$ The terms "malice champerty," "market champerty," and "public champerty" are the inventions of the author.

${ }^{15}$ See Osprey, Inc. v. Cabana L.P., 532 S.E.2d 269, 277 (S.C. 2000) (“[W]e abolish champerty as a defense. We are convinced that other well-developed principles of law 
cient," and "rare," by our courts." ${ }^{18}$ As long ago as 1816, champerty was considered a "hard-named and little-heard-of practice." This Part proposes that champerty has not become obsolete; rather, it has become such a background principle of law that it is invoked under its own name infrequently. This Part will subsequently survey the champertous constituency-groups concretely affected by the state's approach in dealing with champerty.

\section{A. Champerty's Importance Exceeds Its Mention}

The doctrine of champerty has become obscure. From state to state, the very definitional elements of champerty vary. Even where state law arguably permits champerty, the point is too little-known and tentative for extensive use by planners. As a result, few champertous contracts are made and fewer are challenged. Judicial neglect, the conflation of the doctrine with related principles, and the creation of independent ethical constraints on lawyers all have contributed to the quiescence of champerty under its own name.

\section{Definitions: Confusion Run Riot}

Generically, the doctrine of champerty prohibits the sale of the fruit of legal judgment or settlement, in advance of such judgment or settlement, to an otherwise disinterested party. ${ }^{20}$ State courts and legislatures have added to these basic requirements elements suggested to them by legal history or modern policy. In states such as Florida and North Dakota, a contract is not champertous unless the champertor, acting as an "officious intermeddler," provoked or guided the

can more effectively accomplish the goals of preventing speculation in groundless lawsuits than ... dated notions of champerty.").

${ }^{16}$ See Saladini v. Righellis, 687 N.E.2d 1224, 1227 (Mass. 1997) ("To the extent that we continue to have the concerns that the doctrine of champerty was thought to address, we conclude that it is better to do so directly, rather than attempting to mold an ancient doctrine to modern circumstances.").

${ }^{17}$ See Macke Laundry Serv. L.P. v. Jetz Serv. Co., 931 S.W.2d 166, 171 n.1 (Mo. Ct. App. 1996) ("[T] he common law actions of [champerty and maintenance] are rare in modern times, having been replaced by the causes of action of abuse of process, wrongful initiation of litigation and malicious prosecution." (citation omitted)).

${ }_{19}$ Reich hart v. City of New Haven, 674 N.E.2d 27, 32 n.3 (Ind. Ct. App. 1996).

19 JEREMY BENTHAM, DEFENCE OF USURY 3 (1816), available at http:// panoramix.univ-paris1.fr/CHPE/Textes/Bentham/Usury/usury.html.

${ }^{20}$ Supra note 1 and accompanying text. Other definitions are explored in this Part and surveyed in the Appendix. 
suit. ${ }^{21}$ In New Hampshire, only someone who buys a suit with the purpose of promoting litigious strife can be a champertor. ${ }^{22}$ In Kansas, only someone who "frequently excit[es] and stir[s] up quarrels" will have her assignments barred as champertous. ${ }^{23}$ Other states bar champerty even if the champertor entered into the contract at the assignee's urging and for the best of intentions. ${ }^{24}$ Contingency fees for lawyers' services are generally exempted from the champerty rule. ${ }^{25}$ Some jurisdictions, however, seem to apply their champerty laws only to those lawyers who overstep the limits of that exception. ${ }^{26}$ In Maryland and Virginia, it is no longer champerty for a tort sufferer to assign the fruits of her personal injury suit to her treating hospital, up to the value of the care she received for the same injuries.

These states have chosen to narrow champerty's scope by adding elements to its definition. Other states' courts strike down agreements that, while not technically champertous, are close enough to draw judicial ire. ${ }^{28}$ For example, in Wilson $v$. Harris, the Alabama

${ }^{21}$ See Kraft v. Mason, 668 So. 2d 679, 682 (Fla. Dist. Ct. App. 1996) ("[O]fficious intermeddling is a necessary element of champerty."). That is, the champertor must seek out the real party in interest and encourage or guide the suit, "offering unnecessary and unwanted advice or services." Id. (citation omitted). For a similar holding by the North Dakota Supreme Court, see Interstate Collection Agency v. Kuntz, where the court stated: "While the authorities differ as to all the ingredients essential to constitute champerty, they seem agreed that the gist of the offense is the malicious or officious intermeddling in a suit in which the intermeddler has no interest."' 181 N.W.2d 234, 242 (N.D. 1970) (quoting Rohan v. Johnson, 156 N.W. 936, 937 (N.D. 1916)).

${ }_{22}$ See Markarian v. Bartis, 199 A. 573, 577 (N.H. 1938) ("It is our conclusion that, except for those cases where it is found as a fact that litigious strife is sought to be promoted, the rule against champerty and maintenance is not now in force in this jurisdiction.").

${ }^{23}$ Boettcher v. Criscione, 299 P.2d 806, 811 (Kan. 1956) (emphasis added).

${ }^{24}$ See, e.g., Miss. CODE ANN. \$ 97-9-11 (1999) (making it a crime to give any "thing of value ... as an inducement to any person to commence or prosecute further . . any proceeding in any court").

${ }^{25}$ See generally Karsten, supra note 12 (tracing the history of contingency fee jurisprudence and its expanded use in the latter half of the nineteenth century).

${ }^{26}$ See, e.g., Smith v. Childs, 497 N.W.2d 538, 540 (Mich. Ct. App. 1993) (“[T]he defense of champerty does not exist in Michigan except as specified by statute with regard to attorneys.")

${ }^{27}$ See Hernandez v. Suburban Hosp. Ass'n, 572 A.2d 144, 148 (Md. 1990) (allowing for the prejudgment assignment of personal injury awards to health care providers, in light of public policy); In re Musser, 24 B.R. 913, 922 (W.D. Va. 1982) (proscribing the assignment of causes of action for personal injury, but allowing a hospital to "obtain[] an equitable assignment of the sums to be recovered by an individual from a tortfeasor to the extent of the value of the services provided by the hospital in treatment of the individual's personal injuries").

${ }_{28}$ See, e.g., Miller v. Calvin, No. CIV.A.82-C-2253, 1984 U.S. Dist. LEXIS 21057, at *26 (D. Colo. Dec. 20, 1984) (denying the certification of a class action that had "the 
Court of Civil Appeals refused to enforce a contract that "[did] not satisfy all the requirements for champerty," because the court believed that the contract "nevertheless violate[d] the public policy against gambling and speculating in litigation."

In short, confusion reigns over what the doctrine of champerty is and to whom it applies. Failure to create a close band of champerty standards necessarily stifles prosecution, limits champerty's application as a contract defense, and retards public and scholarly interest. ${ }^{30}$

\section{Too Obscure to Challenge}

Aside from the few states that attach criminal sanctions to champerty, ${ }^{31}$ champerty's most visible impact is as a contract defense. Therefore, champerty's presence in caselaw is limited by the volume of champertous contracts.

The shifting and absent champerty standards described in this Part suggest the risk premiums on such contracts are prohibitive. The information cost of assessing the state's champerty laws and the merits of the underlying suit is substantial, especially for a layperson. Except for a few repeat buyers of lawsuits who can minimize their costs, ${ }^{32}$ and investors in suits with the prospect for substantial profit, ${ }^{33}$ most champertors probably make the deal in ignorance of the law. ${ }^{94}$ If the assignee of the legal judgment is equally ignorant of the law, and does not plead the defense of champerty, many courts hold that the de-

taint of collusion, champerty and maintenance").

${ }^{29} 688$ So. 2d 265, 270 (Ala. Civ. App. 1996).

30 In one (admittedly crude) measure of how little champerty is discussed in legal literature, a LEXIS search run on March 1, 2002, revealed that seven years had passed since any law review piece had "champerty" in its title. In that same period of time, "class action" was the title topic of 240 pieces, "attorney's fees" was the title topic 118 times, and "abuse of process" and "malicious prosecution" combined for 18.

s1 See, e.g., ME. REV. STAT. ANN. tit. 17-A, \$ 516(3) (West 1964) (making "champerty" a Class E crime under Maine law). A Class $\mathrm{E}$ crime is punishable by a fine of up to $\$ 1000$. Id. $\$ 1301$ (1)(e) (West Supp. 2001). The defendant also may be sentenced to a term in county jail for up to 6 months. Id. $\S 1252(2)$ (e).

${ }^{32}$ Dobner laid out the theoretical anatomy of such repeat players. See Dobner, supra note 13 , at $1539-43$ (describing Champerco, a hypothetical litigation investment company).

${ }^{83}$ See id. at 1530 (citing successful examples of lawsuit syndication).

${ }^{84}$ In fact, the author conducted an interview with one champertor who lends as much as $\$ 100,000$ in cases nationwide; this champertor did not know his contracts were void in dozens of states. Telephone Interview with Anonymous Champertor (Jan. 15,2002 ) (on file with author). 
fense is waived. ${ }^{35}$

Because champerty is economically inefficient for one-time buyers below a high level of capitalization, few such contracts are made and fewer are contested, and virtually none on the precise grounds of champerty. Ari Dobner may yet be right that there is a substantial unsatisfied market for tort claims, ${ }^{36}$ and Peter Choharis may be correct that such a market would yield enormous benefit, ${ }^{37}$ but in the absence of reliable law, that market will not develop.

\section{Judicial Neglect}

Even considering this paucity of material, some states have a remarkably underdeveloped caselaw on champerty. A Washington State Court of Appeals wondered aloud: "It is questionable whether many remnants of [champerty and maintenance] doctrines remain in this state." A Delaware Superior Court divined the viability of that state's champerty doctrine: "In [Compaq Computer Corp. v. Horton"], the [Delaware] Supreme Court noted that the activities of the plaintiff constituted neither champerty nor maintenance, implicitly recognizing the continuing validity of the doctrines under Delaware law." ${ }^{40}$ State appellate courts in Louisiana, Nebraska, Utah, and Vermont have

${ }^{35}$ See, e.g., Croco v. Or. Short Line R.R. Co., 54 P. 985, 988 (Utah 1898) (holding that the common law of champerty and maintenance is a contract defense that must be plead or lost). But cf. Neal Devins, Asking the Right Questions: How the Courts Honored the Separation of Powers by Reconsidering Miranda, 149 U. PA. L. REV. 251, 261 (2000) ("The duty of courts to look to the law, not just the arguments of litigants, implies that courts can ... address issues necessary to the resolution of the case that neither party raises in briefs or oral arguments.").

${ }_{36}$ See Dobner, supra note 13, at 1590 ("[T] heoretical gains of trade suggest the existence of a market for investing in litigation."); id. at 1530 (citing successful examples of lawsuit syndication); see also Donald L. Abraham, Investor-Financed Lawsuits: A Pro posal to Remove Two Barriers to an Alternative Form of Litigation Financing, 43 SYRACUSE L. REV, 1297, 1297 (1992) ("In the investment world a return of $1,600 \%$ in about nine years would be considered extraordinary to say the least.").

${ }^{37}$ See Peter Charles Choharis, Creating a Market for Tort Claims, REguldation, at http://www.cato.org//pubs/regulation/reg18v4c.html (last visited Mar. 21, 2002) ("A market in which tort claims may be bought and sold to those most able to bear the risks and costs of litigation will benefit both tort victims and defendants, and will reduce the cost of the tort system generally.").

${ }^{38}$ Giambattista v. Nat'l Bank of Commerce, 586 P.2d 1180, 1186 (Wash. Ct. App. 1978) (emphasis added).

${ }^{39} 631$ A.2d 1, 5 n.1 (Del. 1993).

${ }^{40}$ Hall v. State, 655 A.2d 827, 830 (Del. Super. Ct. 1994), aff'd, No. 383 1994, 1995 Del. LEXIS 395, at*7 (Del. Oct. 27, 1995) (emphasis added). 
barely mentioned champerty in the twentieth century. ${ }^{41}$ The idea that champertous litigation contracts have not surfaced in these states in a century strains credulity. It is the language, not the problem, of champerty that these states have avoided.

\section{Conflation of the Doctrine with Related Principles}

Instead of recognizing and rationalizing a doctrine of champerty, the modern tendency is to have related doctrines do champerty's work. All of these substitutions, however, are problematic: they either reconstitute the champerty prohibition under a new name or fail to curb the evils that historically have required the doctrine. A discussion of some of these substitutions follows, including a discussion of abuse of process and malicious prosecution, and unconscionability, duress, and good faith.

\section{a. Abuse of process and malicious prosecution}

The Supreme Court of Idaho has held that:

While Idaho law does not recognize champerty and maintenance, Idaho law is in accord with the many states which continue to recognize that the goals of champerty and maintenance provisions are still around and well, both defensively and offensively, in the form of actions or defenses based on abuse of process or malicious prosecution of civil actions. ${ }^{42}$

Tort actions of malicious prosecution and abuse of process deter the filing of frivolous suits. They do nothing, however, to discourage the assignment of future judgments in meritorious suits. "An action for abuse of process cannot be maintained where the process was employed to perform no other function than that intended by law. ${ }^{49}$

In its strongest form, champerty is a doctrine about how lawsuits get financed, not about which lawsuits get financed. As explored in Part II.B, market champerty (the funding of meritorious suits in the pursuit of profit) can be just as disruptive as malice champerty (the funding of bogus suits to vex, injure, or annoy). Torts of abuse of process do nothing to stem or regulate market champerty. lumbia).

${ }_{42}$ Wolford v. Tankersley, 695 P.2d 1201, 1222 (Idaho 1984).

43 AM. JUR. 2D Abuse of Process $\$ 5$ (1994). 
b. Unconscionability, duress, and good faith

In abolishing its long-standing champerty doctrine, Massachusetts put stock in "the doctrines of unconscionability, duress, and good faith." ${ }^{44}$ If a champertous agreement is contested, Massachusetts resolves that "[w]e shall be guided in our analysis by a rule of what is fair and reasonable, looking to all of the circumstances at the time the arrangement is made to determine whether the agreement should be set aside or modified." ${ }^{45}$ The doctrines of unconscionability, duress, and good faith make no distinction between market champerty and any other commercial transaction:

The basic test [of substantive unconscionability under Massachusetts law] is whether, in the light of the general commercial background and the commercial needs of the particular trade or case, the clauses involved are so one-sided as to be unconscionable under the circumstances existing at the time of the making of the contract. ${ }^{46}$

The Massachusetts rule for duress requires that the claimant show "'he was actually induced by the duress or undue influence to give his consent, and would not have done so otherwise.",47 The commercial law in Massachusetts defines "good faith" as "honesty in fact in the conduct or transaction concerned."

All of these rules protect the rudiments of valid contracting: fair process, uncoerced consent, and absence of fraud. But the doctrine of champerty is only partially motivated by concern for unsophisticated tort plaintiffs defrauded by savvy champertors. ${ }^{49}$ Even if every champertous contract were a win-win proposition, an unregulated private market for champerty would impose substantial externalities on and through the court system. ${ }^{50}$ Ad hoc supervision by the judiciary

${ }^{44}$ Saladini v. Righellis, 687 N.E.2d 1224, 1227 (Mass. 1997).

${ }^{45} I d$.

${ }^{46}$ MASS. GEN. LAWS. ANN. ch. 106, $\$$ 2-302 cmt. 1 (West 2000).

${ }^{47}$ Freeman v. Teeling, 194 N.E. 677, 679 (Mass. 1935) (quoting SAMUEL WiLLISTON, WILLISTON ON CONTRACTS $§ 1604$ (1st ed. 1920)); see also Patsky v. Suprenant Cable Corp., No. 97-2527A, 2001 Mass. Super. LEXIS 367, at *6 (Mass. Super. Ct. Aug. 2, 2001) (" $[\mathrm{T}]$ o prevail on the issue of duress [plaintiff] . . . must demonstrate wrongful or coercive conduct on the part of the defendant which served to overcome his mind and will and which resulted in his executing a contract that he would not otherwise have signed ....").

${ }^{48}$ McCarthy, Kenny \& Reidy, P.C. v. First Nat'l Bank of Boston, 524 N.E.2d 390, 393 (Mass. 1988) (quoting MASS. GEN. LAWS. ch. 106, $\$ 1-201$ (West 1986)).

${ }^{49}$ Cf. Dobner, supra note 13 , at 1545 ("There is also a hint of paternalism in some of the earliest examples of the rule against champerty.").

${ }^{50}$ See infra Part II.B.1 (discussing the externalities that occur when the court treats 
does not suffice to stem these harms.

The Saladini court's claim that it will consider "what is fair and reasonable" in determining "whether the agreement should be set aside or modified"51 goes well beyond the basic commercial doctrines and standards enunciated above. The court draws a specious analogy between its power to regulate attorneys' fees and this newly found power to substantively rewrite litigation-funding contracts. ${ }^{52}$ The judiciary can regulate the bar because attorneys are officers of the court, because attorneys have a monopoly on legal services, and because the state legislature or constitution has so entrusted the courts. ${ }^{53}$ None of those rationales works here. Potential financiers of lawsuits pledge nothing to the court, fiercely compete with other capital providers, and are directly regulated by state commercial law. The power to alter substantively the bargain struck between champertous assignor and assignee flows to the court through no modern doctrine or custom. ${ }^{54}$ The power is simply the prohibition on champerty in disguise.

\section{c. Contrary to public policy}

Meanwhile, " $[\mathrm{t}]$ his common law doctrine of champerty and maintenance, as applied to civil actions, has never been adopted in Connecticut, and the only test is whether a particular transaction is against public policy." ${ }^{55}$ In practice, Connecticut's test always voids tradition-

market champerty like any other commercial transaction). The court in Saladini attempted to address this problem of externalities with a final, cryptic footnote: "Our ruling today should not be interpreted to indicate our authorization of the syndication of lawsuits." 687 N.E.2d at 1228 n.7. If the court means that it still forbids the syndication of lawsuits, it is difficult to see under what authority it does so, if not the principle of champerty which it claims to have abolished. For instance, if contracts governing the syndication of lawsuits are per se against public policy, it can be only for the same reasons that animated the champerty doctrine.

${ }^{51} 687$ N.E.2d at 1227; see also id. (citing cases which indicate the court has the authority to give attormeys fair and reasonable compensation instead of champerty).

${ }^{52}$ See id. ("[O]ther devices ... more effectively accomplish ... [the prohibition on champerty's] ends. Our rule governing contingent fees between attorneys and clients is based on the principle that an attorney's fee must be reasonable. We also recognize a public policy against the recovery of excessive fees." (citations omitted)).

${ }^{59}$ See, e.g., Supreme Court of Va. v. Consumers Union, 446 U.S. 719, 721-24 (1980) (describing the Supreme Court of Virginia's inherent and statutory authority to regulate the bar).

${ }^{54}$ See E. Allan Farnsworth, Farnsworth ON Contracts $\$ 4.1$ (2d ed. 1998) (explaining that of the three traditional methods by which courts can police contracts, they have been "most reluctant to view the problem in the ... perspective ... of substantive unfairness").

${ }^{55}$ Robertson v. Town of Stonington, No. CV950534631, 1999 Conn. Super. LEXIS 
ally champertous contracts. ${ }^{56}$ As the public interest in preventing both malice and market champerty overshadows any private considerations of utility, this is the expected result.

\section{Independent Ethical Prohibitions on Attorneys}

The savviest purchaser of any plaintiff's suit is probably her own lawyer. The incidence of such champerty in contract law has diminished because the state bars have laid out disciplinary remedies against attorneys who "acquire a proprietary interest in a cause of action or subject matter of litigation the lawyer is conducting for a client."

Of course, plaintiffs' lawyers do regularly obtain chunks of future legal judgment or settlement by way of accepting contingency fees. ${ }^{58}$ We ought to acknowledge that contingency-fee lawyers are champertors and then use the ethical guidelines under which those attorneys are regulated to develop models for broader champerty.

\section{Conclusion: Champerty Vital and Irreplaceable}

For all of the modern doctrines dedicated to closing the courtroom to those who would litigate maliciously, no doctrine protects against a flood of litigation for profit. For that reason, the prohibition on champerty remains an irreplaceable prophylactic. The strongest evidence of champerty's influence is in what it has prevented. Despite persuasive evidence that a private market in legal judgments would yield substantial economic benefits, ${ }^{59}$ no such market has been recognized formally or encouraged in any state. Aside from accidental champerty, legal judgment buyers have emerged only where the prohibition on champerty seems absent. ${ }^{60}$ Champerty, under many definitions and scattered throughout statutes, regulations, and common

592, at*8 (Conn. Super. Ct. Feb. 17, 1999), affd, 750 A.2d 460 (Conn. 2000).

${ }^{56}$ Cases where a stranger helps a poor plaintiff secure her rights without concern for payments from the judgment do not count as against public policy-but neither would they count as champerty. Id. at *8-9.

${ }^{57}$ MODEL RULES OF PROF'L CONDUCT R. 1.8(j) (1999).

${ }^{58}$ I refer the interested reader to Sarah Northway's excellent work on the ethics of attorney investment in lawsuits, Sarah Northway, Note, Non-traditional Class Action Financing and Traditional Rules of Elhics: Time for a Compromise, 14 GEO. J. LEGAL ETHICS 241 (2000).

${ }^{59}$ See supra notes 36-37 (citing sources); see also Peter Charles Choharis, A Comprehensive Market Strategy for Tort Reform, 12 YALEJ. ON REG. 435, 435 (1995) (outlining "the basic features of a market for selling, purchasing and trading tort claims").

${ }^{60}$ See Appendix (mapping areas of hostility toward and tolerance of champerty in the fifty states and the District of Columbia). 
law, is parent to many principles and a vital and continuing force.

Yet, what would happen if state legislatures created the commercial and legal conventions needed for an active, open, and permanent market for future judgments? The following Section analyzes the social effects of a definite "private champerty allowed" rule and of a definite "champerty not allowed" rule. While neither is wholly satisfactory, the hypotheticals highlight the dangers to be avoided and opportunities to be exploited should a state create a system of public champerty.

\section{B. Groups to Whom Any Champerty System Must Answer}

Law responds to human need; if champerty is a matter of social indifference, it is also likely a matter of legal indifference. This Section argues quite the opposite. A state laying down a rule regarding the permissibility of champerty should know that it is treading on dangerous ground. In the abstract, the administration of justice and the promotion of social welfare are implicated. For at least ten groups, under either a "private champerty allowed" rule or a "champerty not allowed" rule, the stakes are much more concrete. The deliberating state should be prepared to answer each group and draft a plan that addresses the bulk of their concerns. The following Sections illustrate some of the issues faced by these specific constituencies in a state making a best-faith effort to address the challenges and prospects of champerty.

\section{Under a "Private Champerty Allowed" Rule}

Suppose a state legislature abolishes its prohibition on champerty; champertous contracts, it decides, should be treated the same as any other commercial agreement. Further, assume the torts of malicious prosecution and abuse of process are sufficient to screen out frivolous suits funded for the purpose of injuring, vexing, or annoying the defendant. Among those who would be hurt if the state's commercial law supported unlimited and unregulated funding of meritorious lawsuits, i.e., market champerty, would be: (1) plaintiffs who sell for too little; (2) the wards of deep pockets; (3) those hit harder than the legislature intended; (4) the offended society; and (5) the weary, weary courts.

Plaintiffs who sell for too little. A newborn is permanently crippled by a reckless obstetrician. Her parents, ignorant of the law, sell her malpractice claim for far less than the court would have awarded, or 
even approved of, in a settlement for a similar class action suit. ${ }^{61}$

The wards of deep pockets. A city bus, whose driver is exercising due care, is rear-ended. Upon exiting the bus, passengers see a billboard advertisement: "Have you been injured in an accident? Don't want to deal with lawyers and wait for money? Sell to us now! 1-800-CHAMPTY!" Inspired by the billboard, many passengers not otherwise inclined to sue the city enter into deals to do so. The city, which might have decided to fight more typical plaintiffs, now settles even marginal suits underwritten by claim companies with seemingly limitless war chests. $^{62}$ As the settlements pile up, city services to the poor are torn down. $^{69}$

Those hit harder than the legislature intended. Suppose the legislature creates a new cause of action, good against bioethicists whose negligent advice contributes to medical harm done to subjects in research trials. $^{64}$ The legislature strategically sets a high potential punitive award capped at ten times compensatory damages, knowing that most cash-strapped plaintiffs will only get a fraction of this in settlement. ${ }^{65}$

${ }^{61}$ This group is partially shielded by the doctrine of unconscionability. See supra Part II.A.4.b (describing Massachusetts' use of unconscionability, duress, and good faith doctrines to protect parties to contracts). In some states, however, the requirements of this doctrine are laid out so stringently that it can virtually never be invoked. See, e.g., Christian v. Christian, 365 N.E.2d 849, 855 (N.Y. 1977) (“[A]n unconscionable bargain has been regarded as one "such as no [person] in his [or her] senses and not under delusion would make on the one hand, and as no honest and fair [person] would accept on the other." (last three alterations in original) (citations omitted)).

${ }^{62}$ The suits envisioned here are not frivolous, but rather marginal-neither side can predict with any certainty the outcome of the case. It will cost defendants more to prepare responses to suits funded by professional litigation companies, and the threat that plaintiffs funded by such companies will maintain the suit to trial is more credible.

${ }^{63}$ Services to the poor are most vulnerable to the rollback of public spending, as they are the constituency least courted by politicians. See F. Allan Hanson, Why Don't We Care About the Poor Anymore?, HumaNist, Nov.-Dec. 1997, at 11 ("Politicians could dismantle federal welfare programs without political risk because the non-poor have replaced their former compassion for the poor with indifference, even hostility.").

While a city was used in this example, the same holds true for large private enterprises which make inviting targets for nuisance suits. For example, the phrase, "what's good for America is good for General Motors, and vice versa," see Linda A. Mabry, Multinational Corporations and U.S. Technology Policy: Rethinking the Concept of Corporate Nationality, 87 GEO. L.J. 563, 596 \& n.126 (discussing the origins of this "old adage"), holds at least a kernel of truth. If General Motors is rocked with lawsuits, jobs will be lost; workers partially compensated with profit-sharing or stock options will be hurt, and relied-upon pensions heavy on blue-chip equity investment will deteriorate.

${ }^{64}$ Thanks to Aimée Kahan for suggesting this example.

${ }^{65}$ This section does make certain nontrivial assumptions about potential plaintiffs' financial and legal situations, namely: (1) plaintiffs have no entitlement to public funding to pursue their claim; (2) plaintiffs have no entitlement to public medicine 
If champerty is allowed, investor-backed plaintiffs no longer will be cash-strapped, with the result that bioethicists may be hit much harder than originally intended by the legislature. ${ }^{66}$

The offended society. A plaintiff suing for the intentional tort of forcible battery sells her judgment in advance to a billion-dollar claim company. Everything she does in court-accusing the defendant, describing the alleged acts, asking the jury for vindication and compensation-arguably is done as a proxy for that company's economic benefit. ${ }^{67}$

The weary, weary courts. Champerty will create more work for the already overburdened judiciary. For instance, original plaintiffs will try to weasel out of champertous contracts when the investors get a windfall. Then, investors will sue the plaintiffs when the case unexpectedly comes up dry. Claims that would have settled will now drag on to the last dollar of a probable award. And so on.

As I have shown, each of the above groups would suffer from a total repeal of the prohibition on champerty. Treating market cham-

and those suffering from substantial, tortiously-inflicted injuries will also have sizeable medical bills; (3) a significant percentage of potential plaintiffs cannot afford to finance these bills over the life of a tort suit, which may coincide with a period of unemployability; and (4) the worse the tort, the more likely the plaintiff will feel forced to settle. Where these conditions do not exist, the effect of market champerty is substantially less.

${ }_{66}^{6}$ This is true both now (current bioethicists will shy away from tort-rich research environments, to society's detriment) and in the future (potential bioethicists will instead choose fields with less legal exposure, also to society's detriment). Additionally, normal plaintiffs have characteristics that tend to end lawsuits before the last dollar of probable award is spent on their enforcement: they need money right away, become exhausted by the grind of the suit, and/or may need to deal with the defendant again in the future. In the champerty context, the plaintiff's concerns are different; once the plaintiff has sold her future judgment she no longer needs to settle for cash, and since she is contractually obligated to continue the suit, her weariness is no longer a factor.

${ }^{67}$ Tort claims in particular seem to carry with them a moral condemnation such that they cannot be assigned without exciting public indignation. See Richard A. Nagareda, Outrageous Fortune and the Criminalization of Mass Torts, 96 MICH. L. REV. 1121, 1124-25 (1998) (arguing that "recent developments reflect the use of mass tort litigation as a vehicle for moral condemnation of defendants, wholly apart from the causation of harm to tort plaintiffs"); see also Choharis, supra note 59, at 462 ("In the medieval legal mind, a personal right of action, arising out of contract or tort, arose . . . between two persons and those persons alone. For a third party to assume the right of action would have been unthinkable . . . " (footnotes omitted)). But see Henry M. Hart, Jr., The Aims of the Criminal Law, 23 LAW \& CONTEMP. ProBs. 401, 404 (1958). ("What distinguishes a criminal from a civil sanction and all that distinguishes it . . . is the judgment of community condemnation which accompanies and justifies its imposition."). 
perty like any other commercial transaction ignores the substantial externalities such financing imposes. In summary, tort plaintiffs may suffer by trading their pending judgments for too little, but not so little as to trigger an unconscionability defense. Legal sanctions may be magnified by litigation funding beyond the point of prudence or legislative intent. Society may suffer from the open commodification of tort recovery, which is unpalatable because of the moral opprobrium that most nonlawyers attach to the infliction of even negligent harms. Finally, the already overworked court system may suffer from an increased workload.

\section{Under a "Champerty Not Allowed" Rule}

Suppose that after a disastrous year of private champerty, the legislature retracts its sanction. Champerty again will be a defense to the enforcement of litigation-funding contracts. The state legislators, hoping for a return to normalcy, are surprised when complaints continue to be filed. Constituencies that had been asleep to the virtues of champerty now demand its return. Those constituencies might include: (1) socially-beneficial enterprises that cannot otherwise hedge risk; (2) shallow-pocket consumers; (3) those who must settle for less than the legislature intended; (4) offended plaintiffs; and (5) the courts as servants of justice.

Socially-beneficial enterprises that cannot otherwise hedge risk. A "champerty not allowed" rule prevents socially-beneficial enterprises from hedging risk, thereby endangering their continued existence. Consider a pharmaceutical company which, distracted by ever more draconian tort law, shifts resources from the development of new drugs to the marketing of existing drugs. If the company could offset its exposure to new tort laws by investing in products liability claims, it would return to the risky business of making advances in medicine. ${ }^{68} \mathrm{~A}$

\footnotetext{
68 "Hedging offsets the firm's risk, such as the risk in a project, by a set of transactions in the financial markets." STEPHEN A. RosS ET AL., CORPORATE FINANCE 703 (3d ed. 1993).

The basic idea of hedging is this: if you are uncertain whether $X$ or $\sim X$ will occur, bet on both. While total hedging is fruitless, partial hedging limits your risk. Id. at 711,719 . For companies that are engaged in an activity $X$, investing in competing industries or in adverse conditions $(\sim X)$ limits risk. An oil company may purchase futures contracts on natural gas, for example. A newspaper concern may bet, through the futures market, that the cost of paper will rise, even while the concern prays it does not. Cf. id. at 729 ("Many firms are faced with interest-rate risk. They can reduce this risk by hedging with interest-rate futures contracts."). And, if champerty were legal, pharmaceutical companies could buy shares in lawsuits predicated on the very theories
} 
"champerty not allowed" rule blocks that investment and those advances. Consequently, lives are lost.

Shallow-pocket consumers. Shallow-pocket consumers are harmed by a "champerty not allowed" rule because their rights may be trampled since they do not have the resources to enforce those rights. A boat maker negligently skimps on materials used to make a low-end model dinghy. The money that the company saves is spent on supererogatory safety features for a yacht. In-house counsel assures the boat maker's board of directors that the purchaser of the low-end dinghy will settle easily since she likely lacks the financial means to do otherwise, while the buyers of the high-end yachts have the money to pursue full compensation. ${ }^{69}$ If champerty were allowed, investors could fund the suits regardless of the wealth of the plaintiff. Under a "champerty not allowed" rule, every plaintiff must be her own bank.

Those who must settle for less than the legislature intended. Those who are forced by individual circumstances to settle tort claims for less than the legislature intended are also harmed by a "champerty not allowed" rule. For example, the legislature creates a fund to reimburse

against which they must defend. See Choharis, supra note 59, at 510-14 (explaining the economic benefits and hedging possibilities of a secondary market in tort claims). In addition to economic benefit, there is a systemic benefit. If the courts or the legislatures turn the screws of tort liability too tight, the result will not be as economically disastrous to tortfeasor-investors as it would be to unhedged tortfeasors.

For example, Drug- 1 has a $50 \%$ chance of making $\$ 1$ million and a $50 \%$ chance of being worth nothing. Drug-2 . . Drug-n have the same odds. Consider both the value and the volatility of a firm which gradually acquires Drug-1 . . Drug-n at the rate of one per year. At year one, the firm will be worth either: $\$ 1$ million (a $50 \%$ chance) or nothing (a $50 \%$ chance). At year two, the firm will be worth either: $\$ 2$ million (a $25 \%$ chance), $\$ 1$ million (a $50 \%$ chance), or nothing (a $25 \%$ chance). At year three, the firm will be worth either: $\$ 3$ million (a $12.5 \%$ chance), $\$ 2$ million (a $37.5 \%$ chance), $\$ 1$ million (a $37.5 \%$ chance), or nothing (a $12.5 \%$ chance). The prospects of very high and very low payoffs have tapered out, and the risk profile of the firm will continue to flatten as the number of its constantly risky acquisitions grows. Although the underlying assets remain as speculative as ever, the firm's portfolio of experimental drugs has become an ever more conservative investment. Even institutional money, which may be invested only in certain sound instruments, will flow into such portfolios.

Wide-scale champerty permits the same sort of prudent financial hedging. Suppose that the drug industry faced thousands of suits per year, predicated on hundreds of unique fact patterns and dozens of novel theories of recovery. Any particular drug company would be hard-pressed to determine, a priori, which suits would win and which would lose. But, by investing in portfolios of these suits filed against its competitors, a drug company may reduce its industry-specific risks, i.e. the risks it incurs by continuing to operate in a particular industry, to a very conservative amount.

${ }^{69}$ See Dobner, supra note 13, at 1590 ("A plaintiff's risk-bearing ability effects [sic] a plaintiff's decision whether or not to pursue a claim and the amount for which a plaintiff is willing to settle."). 
asbestos victims for the medical harms they have suffered. Because early detection is critical, most healthy but exposed workers settle for fund-sponsored medical monitoring rather than fighting for their fair share of the fund. Well-to-do contractors get the lion's share of the fund because they can pay for their own monitoring and do not opt out of the fund like most of the poorer workers. With champerty, day workers could stay in the fight; without it, they need the money for medical monitoring right now. ${ }^{70}$

Offended plaintiffs. Even meritorious tort plaintiffs are harmed by a "no champerty" rule. Consider a case in which an arsonist burns down a plaintiff's house. A civil suit against the offender likely will take months, as defense counsel might raise complex questions of jurisdiction, causation, and mental capacity. When the plaintiff attempts to sell a portion of her future judgment to a landlord in lieu of rent, she is blocked by the rule against champerty. ${ }^{71}$ Incredibly, she is told that she must bear the legal wrong inflicted on her and cannot exchange her legal hopes for immediate relief. ${ }^{72}$ The civil prosecution of arsonists, she is told, is too morally important to be the object of finance.

The courts as servants of justice. Courts' ability to act as servants of justice may be limited by a "champerty not allowed" rule. The state courts may have been nonplussed by the increase in litigation under the private champerty rule. On the other hand, the business of the courts is reckoning, not rest. ${ }^{73}$ If the flow of meritorious cases is greatly diminished by the re-prohibition of champerty, the courts may

70 To some degree, the overdeterrence and undercompensation arguments of this Part reflect contradictory views of how legislatures set awards-strategically or naively. More important than actual legislative intent, for the purposes of this Part, are the public's understanding of and political response to the awards set.

${ }^{71}$ The predominant modern characterization of legal claims is as economic claims. See, e.g., RiCHARD A. POSNER, ECONOMIC ANALYSIS OF LAW 218 (4th ed. 1992) ("Rape bypasses the market in sexual relations (marital and otherwise) in the same way that theft bypasses markets in ordinary goods and services, and therefore should be forbidden."); Stanley Ingber, Rethinking Intangible Injuries: A Focus on Remedy, 73 CAL. L. REV. 772, 788-89 (1985) ("The trend in tort law . . . has been to distinguish moral wrongdoing from the legal fault of negligence . . . Because negligence-legal faultrequires nothing more than momentary inadvertence, the demand for restitutive justice in such cases is influenced less by moral fault than by rule and expectation violation." (footnote omitted)).

${ }^{72} \mathrm{Or}$, rather, that she is stuck in a monopsonistic market where the only permissible buyer is the one that did her harm.

${ }^{73}$ "Other States that no longer recognize the doctrine of champerty have continued to scrutinize an agreement to finance a lawsuit with care. We shall do likewise." Saladini v. Righellis, 687 N.E.2d 1224, 1227 (Mass. 1997) (citation omitted). 
conclude that persons suffering from legal wrongs no longer can afford to hold out for justice.

For all of these reasons, the "champerty not allowed" rule is also suboptimal. The economic benefits of a market for tort judgments dry up. The least well-off are made to bear legal wrongs. Remedies are not given their full measure. And the doors to the courtroom close. Consequently, it is no great mystery why the state legislatures have not engaged in substantive debate about legalizing private champerty. "Pandora, overcome with curiosity, opens the box, whereupon ten thousand evils fly out of it and begin to plague the life of man, while Hope alone remains." ${ }^{74}$

\section{A Pilot Plan for State ACtion}

As can be seen from Part II.B above, both the "private champerty allowed" and "champerty not allowed" rules are inefficient. Either rule would harm the citizenry. Both yield unjust results. Happily, these polar opposites are not the only options. As this Part argues, a whole spectrum of attitudes toward champerty can be accommodated with one flexible system of public supervision and adjudication. This system of public champerty interposes the authority of the state between assignor and assignee, provides official approval of champertous transactions, and ensures that these transactions, as a group, serve the commonwealth. ${ }^{75}$

A broad outline of such an experiment is sketched below. One state, acting alone, could establish a system of public champerty profitably. Ideally, every state would adopt and adapt a similar system. Under such a system, the rubble of the old champerty statutes and judge-made law would be stripped away. The only avenue of champerty not foreclosed would be a state-run auction. If the assignee and assignor chose to participate, they would waive their rights to a standard state or federal judicial forum. At the discretion of the defendant, the case could be removed to a state-created court of champerty.

The Model Act of Champerty ("the Act") developed in this Part ${ }^{76}$ is tested in Part III.G for its effects on the champertous constituency.

\footnotetext{
742 Will Durant, The STORY of Civilization: THE LifE OF GREECE 101 (Simon \& Schuster 15th prtg. n.d.) (1939).

${ }^{75}$ The author bears full responsibility for bringing the term "public champerty" into the world. May it be better-loved than "stagflation," longer-lived than "costard," and less-abused than "defenestration."

${ }^{76}$ See supra note 4 (noting the Act's origin with the author).
} 
The results suggest that with the proper institutional incentives, public champerty could become a successful, popular system that is also just.

\section{A. The Right Actor to Install Public Champerty Is the State Legislature}

Champerty ought to be normalized and regularized by state legislatures. State legislatures are engines of creation, bastions of plenary governmental power, minor sovereigns. For simplicity's sake, here I consider the assignment of future judgments arising under state law claims, litigated by nondiverse parties.

The logic behind the American federal system is helpful when deciding between a uniform national standard of conduct ${ }^{77}$ and the heterogeneity of independent state action. "The first, and most axiomatic, advantage of decentralized government is that local laws can be adapted to local conditions and local tastes ...., ${ }^{78}$ Because tastes regarding champerty vary wildly from state to state, champerty laws also should be allowed to vary. ${ }^{79}$ As founding father James Wilson described federalism, “[w] hatever object of government is confined in its operation and effect, within the bounds of a particular State, should be considered as belonging to the government of that State." ${ }^{80}$ Here, the state creates the laws under which the parties litigate. Citizenship is nondiverse. Following a Model Code of Champerty, the state creates the laws under which the founding contract is drafted. Either a standard state judicial forum or a state champerty court will decide the case. Wilson could not have devised an action of government more perfectly contained "within the bounds" of a state. "A final reason why federalism has been thought to advance the public good is that state and local governmental units will have greater opportunity and incentive to pioneer useful changes." ${ }^{81}$ Indeed, fifty individual simultaneously running state experiments in public champerty would quickly gather the data necessary to guide all of the systems closer to their social ideal. A unitary system of public champerty would squelch

\footnotetext{
77 "Uniform national standard of conduct" embraces both obligations imposed on the states by federal legislation and schemes in which the states voluntarily adopt a single standard, like the Uniform Commercial Code.

${ }^{78}$ Michael W. McConnell, Federalism: Evaluating the Founders' Design, 54 U. CHI. L. REV. 1484, 1493 (1987) (reviewing RaOul Berger, FEderalism: THE Founders' DESIGN (1987)).

${ }^{79}$ See Appendix (describing the varying champerty laws in the fifty states and the District of Columbia).

${ }^{80}$ McConnell, supra note 78, at 1495 (citation omitted).

81 Id. at 1498.
} 
innovation, prevent competition, and make comparative analysis impossible.

The main drawback of independent state action "is the tyranny of a majority faction. Since any given faction is more likely to be concentrated in a particular locality, . . . it follows that factional tyranny is more likely in the state legislatures than in the Congress of the United States." ${ }^{, 82}$ Under the system of public champerty suggested below, the only time a case gets into a court of champerty is when both plaintiff and defendant put it there. Since both voluntarily forgo a standard judicial forum, neither can claim true factional oppression by the state legislature.

The legislature is a more appropriate forum than the courts in which to establish a rule of workable champerty. The legislature is better at handling the mainly political questions at hand. ${ }^{83}$ Only legislative enactments can provide the positive assurance to potential investors that champerty will indeed be welcome in the future. ${ }^{84}$

\section{B. Define Champerty}

The first step in establishing a system of public champerty must be the creation of an encompassing definition of what the doctrine embraces. $^{85}$

Model Act of Champerty, Section 1: For all state law claims wherein both plaintiff and defendant parties include at least one citizen of this state (a) any transaction is champertous wherein: (1) the assignor is able to bring or continue an action in court; (2) the assignee is not able to bring or continue the same action; (3) the assignee is not an attorney employed as a legal representative of the assignor; ${ }^{86}(4)$ the assignor and

${ }^{82}$ Id. at 1501-02.

${ }^{83}$ See Lochner v. New York, 198 U.S. 45, 76 (1905) (Holmes, J., dissenting) (asserting that our political system is "made for people of fundamentally differing views"). See generally Robert F. Nagel, Political Law, Legalistic Politics: A Recent History of the Political Question Doctrine, 56 U. CHI. L. REv, 643 (1989) (tracing the historical boundary between what is considered political and what is considered judicial).

${ }_{84}$ "Until you have universal, well-protected, clear, and transferable private property rights, you cannot have a market economy . . . ." Dario Fernandez-Morera, Outlaws and Addresses: An Interview with Hernando De Soto, REASON OnLIne II 37 (Feb. 1994), http://reason.com/DeSoto.shtml.

${ }^{85}$ "Tzu-lu said, If the prince of Wei were waiting for you to come and administer his country for him, what would be your first measure? The Master said, It would certainly be to correct language." CONFUCIUS, THE ANALECTS OF ConfuCIUS 171 (Arthur Waley trans., Vintage Books 1989) (1938).

${ }^{86}$ See supra Part II.A.5 (discussing independent ethical prohibitions on attorneys). 
assignee agree prior to final legal judgment or settlement; ${ }^{87}(5)$ and the object of their agreement is that the assignor will give the assignee at least a portion of the eventual fruits of legal judgment or settlement in exchange for consideration furnished prior to final legal judgment or settlement.

This definition does not include the malice elements currently required by some state definitions. ${ }^{88}$

\section{Clear Away the Deadwood}

If champerty is to become a purely public system, all modes of private champerty must be eliminated. Thus, the Model Act of Champerty must start by clearing away traditional systems of private champerty. The most sure-footed way to do this is to predicate state court jurisdiction over champertous contract enforcement ${ }^{89}$ on the production of an evidentiary document.

Model Act of Champerty, Section 2: (a) No person shall be entitled to enforce champertous contracts where the underlying case has not been certified to the trial court with a state declaration of champerty, meeting all of the requirements of section $3(j)$ of this Act. (b) Such contracts shall be interpreted as any other commercial agreement, notwithstanding traditional prohibitions or hostilities against champerty.

Because section 1 of the Act defines champerty so broadly and with so few circumstantial elements, section 2(a) defeats most private champertous contracts immediately. As a result, state residents cannot defeat the prohibition on private champerty by drafting contracts under the laws of another state. ${ }^{90}$ Moreover, with so few circumstantial elements at issue, the public cost of dismissing these private

${ }^{87}$ A useful substitute for the "final legal judgment or settlement" might be "final decision." See Catlin v. United States, 324 U.S. 229, 233 (1945) (“A 'final decision' generally is one which ends the litigation on the merits and leaves nothing for the court to do but execute the judgment.").

${ }^{83}$ See supra Part Il.A.1 (discussing the confusing range of state definitions of champerty).

${ }^{89}$ Impliedly, claims for compensation for the tort of "interference with a champertous contract" also would be beyond state courts' ability to enforce. No tort of interference can be established without first establishing that there was a valid contract with which to interfere. 45 AM. JUR. 2D Interference $\$ 4$ (1999).

${ }^{90}$ The withdrawal of enforceability defeats the Dobner exceptions discussed supra note 13. Regardless of the law selected by the contractors, under this system of public champerty, no litigation-financing contract will be enforced by state courts without a declaration of champerty. The counterparties can file suit in a neighbor-state court without these rules of public champerty if the parties can find a jurisdictional nexus and if the neighbor state wants to spend resources on hearing these claims. 
champerty suits will shrink to the vanishing point.

The remainder of section 2 instructs the state courts to handle publicly certified champerty cases as any other commercial transaction. The procedural safeguards built into the auction system and the procedural rights the system affords to defendants make judicial hostility to champertous suits unnecessary. ${ }^{91}$

\title{
D. Give the Plaintiff a Choice: Keep or Sell
}

\begin{abstract}
Model Act of Champerty, Section 3: (a) Consistent with the provisions of this Act, the state attorney general shall establish and supervise the auctions described herein. (b) Plaintiffs, (1) having filed a suit in a state court, that (2) alleges a violation of state law, shall have the right to sell the judgment of that suit in the manner described herein. (c) To be eligible to sell her judgment, a plaintiff must sign a waiver, forgoing her right to trial in a standard state judicial forum, and accepting the adjudication of the state courts of champerty. The waiver must explain the difference in procedure between the courts of champerty and the standard state judicial forum. (d) To be eligible to buy the judgment, prospective purchasers must sign the same waiver. (e) A panel of experts selected by the attorney general shall set the minimum price at which the suit may be sold. If no bid meets the established minimum, the plaintiff's waiver is null and void. (g) This panel may stay the auction of the suit until such time as the plaintiff can submit enough information for the panel to make a reasonable estimation of its value. (h) The Department of Justice may disqualify the suit from sale if there already have been substantial proceedings on the merits in state court, unless those proceedings were required by the panel to satisfy section 3 (g) of this act. (i) The suit shall be sold to the highest eligible bidder. (j) The Department shall finalize the sale by submitting to the clerk of the trial court a sworn declaration of champerty. Such declarations shall certify the party names, date of sale, minimum bid, final selling price, and the name of the purchaser, and shall indicate the approval of the Department official overseeing the auction. (k) The plaintiff must give notice of this sale to the defendant within five days of the filing of this declaration.
\end{abstract}

This section of the Act provides several important provisions concerning a plaintiff's choice, waiver, timing, auction, certification, and secondary markets. First and foremost, this section guarantees choice for plaintiffs. No plaintiff should have to sell her suit. The choice should be hers: keep her claim to legal judgment and enjoy all of the privileges of judicial forum that attach to it, or sell her entire claim in

${ }^{91}$ See infra Part IV.B (arguing that the fact that these suits will be heard in specialized champerty courts with self-selected champerty judges will reduce judicial hostility to the idea). 
a state-supervised auction. Once the plaintiff makes the choice to sell, she must sign a waiver, agreeing to litigate the suit in the forum of the defendant's choice. All bidders and subsequent purchasers of this claim to legal judgment must sign the same waiver. ${ }^{92}$ Section $3(\mathrm{~g})$ recognizes that some discovery may be necessary for auction participants to get a rough idea of the value of the suit prior to sale. ${ }^{33}$

To make sure that plaintiffs are not swindled, it is important that the state run the auction. Under section $3(\mathrm{e})$, a panel of knowledgeable legal professionals sets the reserve price, the minimum bid acceptable for the claim. ${ }^{94}$ If the reserve price is not met, the waiver is null and void. Otherwise, the highest bidder purchases the claim. ${ }^{95}$ Following the auction, the auctioneer is required by section $3(j)$ to file a declaration of champerty with the clerk of the trial court.

The legislature may draft special rules to govern the resale of legal claims or may treat them as any other financial paper. ${ }^{96}$ At any rate, no legal claim can be resold before the defendant exercises her

${ }^{92}$ See infra Part IV.A for a discussion of the constitutionality of this waiver.

${ }_{93}$ David Friedman, however, suggests that the value of a suit generally can be determined on the basis of very few data points. See generally David Friedman, More Justice for Less Money, 39 J.L. \& ECON. 211, 211 (1996) (analyzing a "radical solution to the problem of litigating mass torts" implemented by a federal judge in Texas, in which samples of the plaintiff class had their case heard, with the results extrapolated to the whole).

${ }^{94}$ Other protections can also be put in place: all bids can be recorded and witnessed; a notary public can be present; a minimum number of bidders can be required to ensure thick markets and accurate price information; the state may require that bidders be bonded; the substance of the information made public can be made uniform in the timing of release to the bidders. Cf. Michael Abramowicz, The Law-andMarkets Movement, 49 AM. U. L. REv. 327, 335-51, 374-409 (1999) (laying out the technical requirements for effective markets in legal claims).

${ }_{95}$ Such a bidder may, in the interest of preserving incentive, sell the plaintiff back a portion of her legal judgment. Alternatively, the state may require such resale as a condition of the plaintiff's participation in the auction.

${ }_{96}$ There might be ethical reasons for establishing special rules, at least regarding investor-attorneys. See infra Part IV.B (noting that the state or state bar should take steps to avoid "insider trading" by lawyers and to control ethical conflicts). The question of whether federal securities law will impose additional registration requirements is beyond the scope of this Comment. See Jennifer Carlucci, Note, Litigation Funding Devices for Franchisees: Are They Securities?, 25 HoFsTRA L. REV. 353, 375 (1996) (noting that "it would not be surprising for investor-financed lawsuits to be found to qualify as securities under federal securities laws"). But see Donald L. Abraham, Investor-Financed Lawsuits: A Proposal to Remove Two Barriers to an Alternative Form of Litigation Financing, 43 SYRACUSE L. REV. 1297, 1319 (1992) ("[B]ecause a literal application of the federal securities laws poses a regulatory hinderance [sic] to the investor-financed lawsuit, an exception should be made ... The exception is warranted because the regulation of lawsuit financing does not further Congress's goals in enacting these laws."). 
choice, as laid out below.

\title{
E. Give the Defendant Three Choices: Match, Remove, or Stick
}

Model Act of Champerty, Section 4: (a) Where a declaration of champerty, satisfying all of the requirements set forth in section $3(j)$ of this Act, has been filed with the clerk of the court, a defendant may: (1) agree to match the selling price set forth in the declaration, in which case the purchaser must sell the suit to the defendant; or (2) remove the case to the state courts of champerty, as established by section 5 of this Act. (b) If the plaintiff exercises neither of these options within thirty days of the filing of the declaration, both options are extinguished, and the case shall stay in the state courts.

With the declaration of champerty filed, the defendant may, within a certain time period, make one of three choices. The defendant's first option is to buy the suit from the highest bidder by matching the auction price paid. ${ }^{97}$ Her second option is to remove the case from the standard state court forum to a state-created court of champerty. Lastly, the defendant may choose to defend the claim in state court.

If the claim is truly frivolous, little money will be paid for it, and the defendant can immediately end the suit by paying that small amount. If the modest merits of the case or the defendant's inferior financial resources make this quick decision an attractive option for the defendant, then she can remove the case to the court of champerty. If, on the other hand, the defendant has a financial advantage over the plaintiff, the defendant can choose the much longer grind of the standard judicial forum.

\section{F. Have the State Make a Choice: Establishing the Courts of Champerty}

\begin{abstract}
Model Act of Champerty, Section 5: (a) We hereby establish a state court of champerty. (b) This court shall have jurisdiction over only those cases wherein a judgment has been sold in advance of auction consistent with the provisions of section 3 of this Act and wherein a declaration of champerty has been filed consistent with section $3(j)$ of this Act and wherein the defendant has exercised her right to remove to the courts of champerty consistent with section 4(a)(2) of this Act. (c) Where the court of champerty has jurisdiction over the case, it shall follow the Rules of Champertous Procedure provided by the state supreme court, to the degree that those rules are consistent with this Act
\end{abstract}

${ }^{97}$ Under the civil law, just such an option is available. For a critique of its operation, see Dobner, supra note 13, at 1552-55. 
the Rules might provide the foundation from which the legislature would subtract. In enacting procedural rules for courts of champerty, the state legislature might consider changing Rules 30-33 to reduce the number of interrogatories and depositions allowed. ${ }^{102}$ Additionally, it might consider abbreviating the discovery schedule under Rule $26^{103}$ or lowering the summary judgment standard under Rule $56 .{ }^{104}$ These are just a few examples of the possible procedural alterations that could be made in developing procedural rules of the courts of champerty.

Alternatively, the state could start with the philosophical bare bones of a fair trial and build up. ${ }^{105}$ The state might also shift from an adversarial to an inquisitional mode. ${ }^{106}$ Under the latter, the judge would be allowed to decide what she would need to know to make a decision and would possess the power and resources to do so. ${ }^{107}$

The states are also not compelled to offer the plaintiff the same amount of procedural protections that it offers the defendant. If the plaintiff opts into a trial with unilaterally reduced procedure, that is her prerogative. A strong case can be presented in a few damning strokes. For example, (1) here is a videotape of the police beating me, (2) here is eyewitness testimony, (3) here is one of the defendant's confessions, and (4) case closed.

Each state has its own attitude toward champerty, willingness to hear champertous suits, resources to so do, fear of over- and underenforcement of legal remedies, and proclivity for or disdain of jurisprudential innovation. This Comment argues that public champerty may be worthwhile independent of the actual procedures adopted by the courts of champerty.

speedy, and inexpensive determination of every action.").

${ }^{102}$ See FED. R. CIV. P. 30-33 (governing the discovery process as it pertains to depositions and interrogatories). The Federal Rules allow a party to take depositions of any person, without leave of court, in most circumstances. Id. The Rules also allow a party to serve twenty-five interrogatories upon the other party. Id.

${ }^{109}$ See FED. R. CIV. P. 26 (setting the ground rules for the discovery process as a whole).

${ }^{104}$ See FED. R. CIV. P. 56 (providing the standard for summary judgment).

${ }^{105}$ See generally Henry J. Friendly, Some Kind of Hearing, 123 U. PA. L. REv. 1267, 1279-95 (1975) (providing a menu of eleven basic procedural elements, each of which make adjudication more fair, but each of which exacts an administrative cost).

${ }^{106}$ Id. at 1289-91.

${ }^{107}$ The judge may not need much information to render an informed judgment. See generally Friedman, supra note 93, at 211 (analyzing a method implemented by a federal judge in Texas, in which samples of the plaintiff class had their cases heard, with the results extrapolated to the whole). 
and with our subsequent legislation. (d) However, the courts must follow the Rules of Champertous Procedure as constituted on the date of the sale, as recorded in the declaration of champerty, regardless of any subsequent judicial revisions. ${ }^{98}$

Those of us trained in U.S. civil procedure take for granted certain robust minimums of procedure. A fair trial, we think, ought to be like a full Article III trial. Philosophically, for a trial to hew to the foundations of what we think of as equity, this need not be so. The original plaintiff chose to sell her claim to legal judgment, and thus voluntarily exposed herself to adjudication in the courts of champerty. The champertor-investors took the same risk, and signed the same waiver. If the courts of champerty are less hospitable for plaintiffs, then that treatment is surely accounted for by the auction price paid. Finally, for a case to arrive in these courts, the defendant must have affirmatively removed it there. Therefore, as long as all of these participants know the rules of adjudication beforehand, any procedure is fair. A coin flip, a reading of the I Ching, an arm wrestling contest between counsel-all of these are fair modes of decision among the people who chose them. To the volunteer, no injury is done. ${ }^{99}$

Thus, in fairness, the state legislature can endow these courts with any mode of adjudication it sees fit. The state, however, has a dignitary interest in the adjudicatory forums that it provides. For this system of public champerty to endure, it must earn the respect of lawyers, the judiciary, and the public at large. While these courts of consent are excellent candidates for vanguard innovations in civil procedure, ${ }^{100}$ the need to establish legitimacy recommends starting with a traditional, well-understood, and well-respected judicial model.

Existing Federal Rules of Civil Procedure provide one traditional judicial model. ${ }^{101}$ Arguably the fullest exposition of trial procedure,

${ }^{98}$ Barring a state constitutional amendment, the state legislature cannot tell the court to ignore future legislative revisions.

${ }^{99}$ As John Rawls put it, explaining his concept of fairness: "[c] onceptions of justice are to be ranked by their acceptability to persons so circumstanced." JOHN RAWLS, A THEORY OF JUSTICE 17 (1971). As many of my readers have noted, Rawls himself likely would disagree with some or all of the conclusions that I have drawn based on this maxim, and hence with some or all of my proposals. To this I can only reply that even John Rawls is entitled, on occasion, to be wrong.

${ }^{100}$ "[A] rbitration also opens the gates of procedural imagination, permitting the parties to provide rules of procedure that differ dramatically from the ones we see in courts ...." STEPHEN C. YEAZELL, CIVIL PROCEDURE 600 (4th ed. 1996).

${ }^{101}$ See FED. R. CIV. P. 1 ("These rules govern the procedure in the United States district courts in all suits of a civil nature whether cognizable as cases at law or in equity or in admiralty .... They shall be construed and administered to secure the just, 


\section{G. Poll the Constituency}

The state should endow the courts with procedure that addresses and answers the concerns of the groups cited above. ${ }^{108}$ The safeguards built into the auction procedure already have answered the concerns raised by the plaintiffs who sell for too little. ${ }^{109}$ Though plaintiffs still may sell for too little, the setting of a reserve price by an expert panel will ensure that the shortfall is not unconscionable, even under the most protective meanings of that term. ${ }^{110}$

The concerns raised by the wards of deep pockets are similarly protected. ${ }^{111}$ The fact that all claims initially must be sold through state-supervised auction mechanisms ${ }^{112}$ diffuses the incentive for prospective buyers to advertise directly to prospective plaintiffs. ${ }^{13}$ Also, the plaintiff must produce not just a colorable claim, but a marketable claim to legal judgment. Plaintiffs that fail to do so will either (1) receive no financing, in which case licensed champerty has not hurt defendants at all, or (2) elicit such minimal bids as to tempt defendants to exercise their prerogative to settle the claim at the auction price.

Those hit harder than the legislature intended can also be protected by legislative action. The legislature can provide two standards of recovery-one for suits in which a declaration of champerty has been filed, and one for all other suits. Suppose, for example, that the legislature had predicted that the average rate of recovery in suits against bioethicists, absent champerty, would be fifty percent of that provided by statute. The legislation could be amended to reduce recovery in the courts of champerty to half of that provided in the standard forum. This provision would eliminate the windfall that otherwise would accrue to fully financed and contractually relentless

${ }^{108}$ See supra Part II.B (noting the concerns of plaintiffs who sell for too little, the wards of deep pockets, those harder hit than the legislature intended, the offended society, and the weary, weary courts under a "private champerty allowed" rule).

${ }_{109}$ See supra note 61 and accompanying text (outlining these concerns).

${ }^{110}$ See supra Part III.D (proposing Model Act of Champerty $\$ 3(\mathrm{e})$, requiring the setting of a reserve price).

11 See supra notes 62-63 and accompanying text (outlining the issues raised by the wards of deep pockets).

${ }^{112}$ Supra Part III.C (proposing Model Act of Champerty $\S 2(a)$ ).

${ }^{113}$ If champerty becomes big business, the demand for claims might be powerful enough to allow all buyers to pay into a joint advertisement pool. Cf. Milk Marketing Board, Got Milk?, at http://www.got-milk.com (last visited Feb. 8, 2002) (exemplifying a highly successful advertising campaign funded by a trade association). The state could ban such advertising as a condition for getting a license to buy at a champerty auction. 
plaintiffs. At the same time, the relative compensatory positions of the defendant and the plaintiff, as originally envisioned by the legislature, would be maintained.

In theory, the concerns of the offended society may be more difficult to mollify. Any system that permits champerty in a thoroughgoing way will offend those who see legal claims as entailing moral claims. The only answer responsive to this group is for plaintiffs to pay for their offense with reduced procedure.

To illustrate this point, suppose $\$ X$ is the cash value of the offense, i.e., how much those offended would have to be paid to accept a system of champerty. $\$ Y_{1}$ is the auction value of the claim if it were entitled to a full trial in a standard state forum. $\$ Y_{2}$ is the auction value of the claim if exposed to the courts of champerty, endowed with whatever procedure the legislature provides. If the legislature equips the courts of champerty so that the difference between $\$ Y_{1}$ and $\$ Y_{2}$ is greater than $\$ X$, then any plaintiff who still chooses champerty is evincing such benefit that it must be considered a net social good. ${ }^{1 / 4}$

If the moral offense is overwhelming, however, then, the procedure might have to be reduced so drastically as to have the same effect as an outright prohibition on champerty. But this reality seems unlikely. Champerty will naturally lose its shock value as it becomes more common. ${ }^{115}$ As role models, the legislatures' and courts' acceptance of champerty will encourage the public to accept it. ${ }^{116}$ In light of these constraints on moral outrage, the not-so-offended society may

114 For example, suppose the society is offended $\$ 100$ by the battery victim selling her judgment to a claims company. If, because of reduced procedure in the courts of champerty, her claim is worth only $\$ 1000$ at auction instead of $\$ 2000$, and she chooses to sell it anyway, the value of the champertous procedure to her is in excess of $\$ 1000$. Since the offense is ten times more valuable than it is detrimental, it produces net social gain. The inequitable distribution of the gain may be ameliorated somewhat by the fact that any person may, at some point, become a plaintiff.

115 "Emile Durkheim, a founder of sociology, posited that there is a limit to the amount of deviant behavior any community can 'afford to recognize.' As behavior worsens, the community adjusts its standards so that conduct once thought reprehensible is no longer deemed so." ROBERT H. BORK, SLOUCHING TOWARDS GOMORRAH 3 (1996) (quoting Daniel Patrick Moynihan, Defining Deviancy Down, AM. SCHOLAR, Winter 1993, at 19 (citation omitted)).

${ }^{116}$ The moral suasion associated with official action is commonly acknowledged in the area of civil rights. See, e.g., Marlene Z. Stanger, Note, Hate Crimes Legislation: Panacea or Protractor of Societal Ills?, 3 S.D. JUST. J. 419, 446 (1995) (concluding that "[c] ritics and cynics may point all they wish to the fact that President Clinton's statements came on the eve of an election year, but by taking a stand against hate crimes and discrimination, he provided the necessary leadership on which emulation may lie"). 
not require any reduction in procedure above the reductions already provided for the protection of the defendant.

Socially beneficial enterprises that cannot otherwise hedge risk will likely be indifferent to the amount of procedure given. The key point of reference for hedging is not cost, but changes in cost. ${ }^{117}$

Harm to shallow-pocket consumers-those who must settle for less than the legislature intended-and offended plaintiffs is reduced by the creation of a publicly supervised market for champertous claims. A consumer who can show a colorable, marketable claim will not be shallow-pocketed for long. Every plaintiff can get exactly what the legislature intended. While some opprobrium has been built into the system for plaintiffs who sell, it is not insurmountable, and, as suggested above, is likely to impede very little.

The weary, weary courts are served in both ways. With the creation of the parallel courts of champerty and the better evidentiary background for champertous agreements, their workload will not increase substantially. Meanwhile, the courts' role as guarantors of justice is served by the fact that claims will not be abandoned on the grounds of poverty and immediate need.

\section{H. Odds and Ends}

Champerty has become so intertwined with companion laws that a statute legalizing public champerty must be clear about the breadth of its intentions.

Model Act of Champerty, Section 6: (a) This Act shall have no effect on the judicial analysis of the assignability of chose in action. ${ }^{118}$ (b) A plaintiff exercising the procedures laid out in section 3 of this Act is not thereby criminally ${ }^{119}$ nor tortiously ${ }^{120}$ liable. (c) Where the substance of the action funded is a dispute over a claim of property, a declaration of champerty shall negate any statutory holding requirements. (d) The purchaser of a judgment shall have no standing, in any wise, to participate in the case from which judgment is bought. (e) Nothing in this Act shall be construed as allowing for the assignment of the judgment of

117 See supra note 68 (outlining the basics of hedging).

118 See, e.g., Roberts v. Holland \& Hart, 857 P.2d 492, 495-96 (Colo. Ct. App. 1993) (prohibiting assignment of legal malpractice claims, in part because such assignment would "promote champerty").

119 See, e.g., ME. REV. STAT. ANN. tit. 17-A, \$ 516(3) (West 1964) (making champerty a Class E crime under Maine law).

${ }^{120}$ See, e.g., Wolford v. Tankersley, 695 P.2d 1201, 1222 (Idaho 1984) (using "champerty" to mean a tort action available to the defendant in the funded suit, good against the parties to the illicit contract). 
federal claims. (f) For purposes of this statute, no suit or judgment may be sold in its entirety; plaintiff must retain $0.1 \%$ of the claim. (g) No purchase made via the auction system envisioned in section 3 of this Act will be invalidated on the grounds of usury.

This Comment has expressed the prohibition on the assignment of choses as a logical consequence of the prohibition on the assignment of future judgments. ${ }^{121}$ If you cannot sell $X$ (fruit of legal judgment), you cannot sell the right to sue for $X$. The nonassignability of those choses should be preserved so that the claims are funneled into the publicly supervised forum. Section 6(a) of the Model Act dissuades judges from interpreting the establishment of a public champerty as a sign that choses should be freely assignable. Sections 6(b) and $6(\mathrm{c})$ of this Act protect those taking advantage of the public system from criminal, tort, and property sanctions designed to deter private champerty. Section $6(\mathrm{~d})$ limits the champertor's standing in the suit to having an enforceable claim for a portion of the judgment after the fact. Section 6(d) does not prohibit, for example, a public champerty system whereby the assignor must agree with the assignee before accepting a settlement-not that the party in interest would have been denied by the court the right to settle, but that settlement without agreement with the counterparty would be a breach of an obligation with the assignee and hence the subject of a collateral action. Section (f) increases the likelihood that the plaintiff will retain the standing required to be heard in an adverse proceeding before the state court.

\section{Conclusion: Public Champerty Worth Consideration}

The virtues of the system described above are theoretical. The difficulties in drafting, enacting, and administering such a system are, however, eminently practical. In theory, public champerty is a vehicle through which the state can make litigation financing more abundant, scientific, and humane. The Act funnels all champerty into a state system, monitors the auction process for impurities, and then pipes the excess flow into new courts. In practice, such a process is sure to be less than fluid. Drafting such a statute for any individual state will be time consuming since the old concept of "champerty not allowed" goes under many different names, with many different legal ramifications. Enacting the statute may be expensive, both financially and politically. Auction houses and courts need to be established with tax-

\footnotetext{
${ }^{121}$ See Martin, supra note 3, at 83 (expressing the view that a ban on champerty is unnecessary).
} 
payer money, and there is no preexisting constituency for champerty reform. Administering the auctions will be a regulatory headache.

For all its vices, however, a system of public champerty is worth considering. For a state legislature that wants all of the remedies that it provides to be equally effective for all of the citizens that it serves, public champerty should be of obvious appeal.

\section{OBJECTIONS AND RESPONSES}

\section{A. Constitutional Objections}

Does the Due Process Clause ${ }^{122}$ dictate several essential features of fairness required by any trial in which legal rights are adjudicated, even in the courts of champerty? No, the Clause does not constrain our use of alternate dispute resolution in cases of public champerty. Even ex ante, the parties have substantial authority to select the forums and modes of adjudication. ${ }^{123}$ Ex post, the parties can decline to bring a claim to trial at all, continue at trial, raise all claims, or bring an appeal. By implication, the parties have the ex post right to accept a more limited-even expressly biased-trial in exchange for valuable consideration. $^{124}$ Due process in such a case is not denied; rather, due process is offered and bargained away.

\section{B. Prudential Concerms}

Would the creation of a market for legal judgments create a series of ethical problems for lawyers, such as insider trading and unwitting ethical conflicts among others? This is a legitimate concern that states

${ }^{122}$ See U.S. CONST. amend. XIV, $\$ 1$ ("[N]or shall any State deprive any person of life, liberty, or property without due process of law ....").

${ }^{123}$ Parties have the power ex ante to contract themselves into private alternative dispute resolution forums. Cf. Allied-Bruce Terminix Cos. v. Dobson, 513 U.S. 265, 282 (1995) (interpreting a federal statute as requiring state courts to give effect to private arbitration clauses unless they can be invalidated "upon such grounds as exist at law or in equity for the revocation of any contract" (quoting 9 U.S.C. $\$ 2$ )).

Parties also have the power ex ante to agree to forum selection clauses provided there are legitimate reasons for both parties to agree to the clause, and they do not prevent or discourage the pursuit of legitimate claims. See Carnival Cruise Lines, Inc. v. Shute, 499 U.S. 585, 593-97 (1991) (noting that defendant is headquartered in the state selected by the forum clause, that plaintiffs received economic benefit in the form of lowered ticket sales because the defendant's legal costs were consolidated in that state, and that the clause allowed for the judicial resolution of claims).

${ }_{24}$ That plaintiffs have the right to agree ex post to a nonstandard judicial forum is a much more modest contention. 
can readily address. The state or state bar should exclude lawyers from participating in litigation financing altogether, save for their traditional participation in contingency fee arrangements and "blind trust" arrangements wherein the lawyer does not know the content of her litigation portfolio.

Would a system of public champerty encourage the idea that you can select from the menu of torts any you want to inflict, as long as you pay the right price? Maybe. The goals of educative punishment might be better served by pursuing stiffer punitive damages or heightened criminal penalties. The denial of litigation finance options to plaintiffs often will teach the lesson that tortious harms can be inflicted without paying any legal cost whatsoever.

How do you prevent judicial hostility to champertous suits? ${ }^{125}$ As the Model Act of Champerty is written, such hostility is an error of law: " $[t]$ he state court shall interpret and judge this contract as any other commercial agreement, notwithstanding traditional prohibitions or hostilities against champerty." lent but effective hostility in the judiciary remains to be seen. One advantage is that many suits will be heard by the courts of champerty, whose judges are employed to hear nothing but champertous suits. Champertous judges will quickly adopt self-supporting rationales for why champerty is good. Other judges may never hear a champertous suit, as most such suits are cordoned off into a specialized system.

Who can tell what a suit is worth? Currently, many small plaintiffs' firms finance their operations through bank loans. The lending banks evaluate the firm's financial prospects by evaluating the firm's portfolio of cases. ${ }^{127}$ The pool of lawsuit evaluators will grow as the opportunity to invest in litigation grows. Any doubt that the finance industry is up to the task of evaluating litigation should be dispelled by an empirical evaluation of the lawsuit investment industry growing up in champerty's absence. ${ }^{128}$

What keeps the plaintiffs interested? Depending on how the auction is structured, the plaintiff may still own a portion of the eventual

\footnotetext{
${ }^{125}$ See Dobner, supra note 13, at 1530 (noting that one lawsuit syndicator "has encountered judicial hostility to its business" (citations omitted)).

${ }^{126}$ Supra Part III.C (proposing Model Act of Champerty $\$ 2(b)$ ).

${ }^{127}$ See, e.g., JONATHAN HARR, A CIVIL ACTION 212-15 (1995) (describing one plaintiffs' firm's successful attempt to secure a bank loan based on a portfolio of pending cases).

${ }^{128}$ See George Steven Swan, Economics and the Litigation Funding Industry: How Much Justice Can You Afford?, 35 NEW ENG. L. REV. 805, $821-34$ (2001) (detailing the recent expansion of the litigation funding industry).
} 
legal judgment. Moreover, a prudent state will have the claimpurchaser's entire payment put in trust. From this trust, the plaintiff's living, medical, and legal expenses will be paid when incurred. The residue of the trust will be paid to the plaintiff upon either (1) successful completion of the litigation, or (2) a determination, by the claim-purchaser or a neutral arbitrator, that the litigant made every reasonable effort to secure the maximum recovery.

In any case, the auction contract between the assignee and the assignor has an implied covenant of good faith. If the plaintiff's lackluster efforts in advance of her case have caused the assignment of judgment to substantially lose value, then the assignee may allege that this covenant has been broken. ${ }^{129}$ Finally, even a plaintiff with no financial interest in the final judgment may have a lasting collateral interest. For example, the plaintiff may wish to see a tortfeasor pay for her misdeeds, to estop a point of fact from relitigation, or to get an injunction against future misdeeds. Most importantly, the Model Code leaves substantial room for states to perfect practices whereby the plaintiff is kept interested: nothing can change in the courtroom or outside the courtroom, and collateral contractual obligations may obtain; the plaintiff may be held to a higher standard of good faith than a standard contractor; the purchases may have a contractual, though not procedural, right to veto settlement offers; and so on.

\section{Technical Questions}

Who pays the lawyer? Whose personal rights and immunities are before the court? Who gets to decide whether to appeal, what evidence to enter, etc.? The plaintiff makes all of the decisions in the case. She receives the judgment. She pays the lawyer. ${ }^{130}$ It is her rights and immunities that are before the court. Section $6(\mathrm{~d})$ of the Act provides that " $[\mathrm{t}]$ he purchaser of a judgment shall have no standing, in any wise, to participate in the case from which judgment is bought." ${ }^{\text {"1 } 1 ~}$ By leaving total control of the case in the plaintiff's hands, the Act minimizes the impact of the courtroom on champerty. Legal strategy will not twist and turn as the suit is sold and resold. The in-

${ }^{129}$ See Centronics Corp. v. Genicom Corp., 562 A.2d 187, 193 (N.H. 1989) ("[U]nder an agreement that . . . invest[s] one party with a degree of discretion in performance sufficient to deprive another party of a substantial proportion of the agreement's value, the parties' intent to be bound . . . raises an implied obligation of good faith to observe reasonable limits in exercising that discretion ....").

${ }^{180}$ She also is obviously contractually bound to pay the assignee.

${ }^{191}$ Supra Part III.H (proposing Model Act of Champerty $\$ 6(d)$ ). 
terests of counsel will not be divided between her client and the eventual inheritors of the judgment. Although a contractual relationship with investors may exist, no party before the court will be a puppet for any party outside the court. An interesting set of problems may accrue where the plaintiff is offered injunctive relief after seeking money damages. If the champertor has a contractual right to veto settlements, the plaintiff may decide to try an effective breach, or to bargain with the champertor for approval.

Where can a party appeal for reversal of an adverse judgment in the court of champerty? The parties may exercise any of the rights of appeal granted to them by a state's Rules of Champertous Procedure. This may, but need not, include redress to the standard state appellate courts. There is nothing inherently unjust about having no right of appeal. For example, a party over whose claim the United States Supreme Court has original jurisdiction also has no right to appeal. ${ }^{132}$

These complications could be multiplied without difficulty. But in the author's opinion, the often-overlooked abilities of the state legislatures to innovate are more than a match for all possible objections.

\section{CONCLUSION}

As the whole of this Comment has argued, the current litigation financing system causes needless human suffering. A better system must be built, piece by piece. This Comment ends having drawn only in broad strokes. The final blueprints can only be drafted by the state legislatures themselves, adjusting for the unique circumstances of the land and people over which they retain residual sovereignty. preme Court shall have original Jurisdiction."). 


\section{APPENDIX: CHAMPERTY LAW FROM THE FIFTY STATES}

The following overview of champerty law in the United States is offered for three reasons. First, it showcases the patchwork that is modern champerty law. Second, as best the author can ascertain, the cases and statutes cited represent the current law of champerty in each jurisdiction. Third, this compilation is offered for the benefit of future inquirers into champerty, as a mess of raw materials from which champerty's vocabulary, reasoning, and trajectory can be extracted for analysis.

Alabama. Wilson $v$. Harris: An Alabama court refused to enforce a contract that "does not satisfy all the requirements for champerty," because "it nevertheless violates the public policy against gambling and speculating in litigation." 688 So. 2d 265, 270 (Ala. Civ. App. 1996).

Alaska. Wichman v. Benner: The Alaska Supreme Court recently alluded to, but did not define, a "public policy against champerty and maintenance." 948 P.2d 484, 487 (Alaska 1997).

Arizona. Landi $v$. Arkules: The "doctrine of champerty or maintenance does not apply in Arizona." 835 P.2d 458, 464 n.1 (Ariz. Ct. App. 1992).

Arkansas. Bennett $v$. NAACP: In the latest Arkansas case to mention champerty, according to a LEXIS search, the Arkansas Supreme Court struck down as unconstitutional a state antichamperty law that would "make[] the single act of proposing that a fellow man litigate, regardless of intention or the merits of the proposed litigation, or regardless of the good intentions of the proposer, a felonious act in this society punishable by heavy fine and imprisonment." 370 S.W.2d 79, 82 (Ark. 1963) (citation omitted).

California. Abbott Ford, Inc. v. Superior Court: "California ... has never adopted the common law doctrines of champerty and maintenance ...." 741 P.2d 124, 141-42 n.26 (Cal. 1987).

Colorado. Miller v. Calvin: A federal district court sitting in Colorado denied certification of a class action which had "the taint of collusion, champerty and maintenance." No. CIV.A.82-C-2253, 1984 U.S. Dist. LEXIS 21057, at*26 (D. Colo. Dec. 20, 1984).

Roberts $v$. Holland $\mathcal{E}$ Hart: The assignment of legal malpractice claims was prohibited, in part because such assignment would "promote champerty." 857 P.2d 492, 495-96 (Colo. Ct. App. 1993).

Casserleigh $v$. Wood: However, the Colorado Court of Appeals has 
suggested that champerty per se is not prohibited under state law. 59 P. 1024, 1026-27 (Colo. Ct. App. 1900).

Connecticut. Robertson $v$. Town of Stonington: "This common law doctrine of champerty and maintenance, as applied to civil actions, has never been adopted in Connecticut, and the only test is whether a particular transaction is against public policy," and an agreement in which a stranger helps another assert a right for a share of the proceeds is contrary to public policy. No. CV950534631, 1999 Conn. Super. LEXIS 592, at *8, *9 (Conn. Super. Ct. Feb. 17, 1999), aff'd, 750 A.2d 460 (Conn. 2000).

Delaware. Hall $v$. State: "It is the duty of [this Delaware] court to dismiss a case in which the evidence discloses that the assignment of the cause of action sued upon was tainted with champerty," because "[i]n [Compaq Computer Corp. v. Horton, 631 A.2d 1 (Del. 1993)], the [Delaware] Supreme Court noted that the activities of the plaintiff constituted neither champerty nor maintenance, implicitly recognizing the continuing vitality of the doctrines under Delaware law." 655 A.2d 827, 830 (Del. Super. Ct. 1994), affd, No. 383 1994, 1995 Del. LEXIS 395 (Del. Oct. 27, 1995).

District of Columbia. Marshall $v$. Bickel: The court explained that in a champertous fee arrangement, "(1) the attorney's fee must come from the recovery in a successful lawsuit; (2) the lawyer must have no independent claim to the recovery fund; and (3) the costs and expenses must be borme by the attorney with no expectation of reimbursement from the client," stated that a contract deemed to be champertous will not be enforced by the District of Columbia courts, and held that "the attomey will be denied even quantum meruit recovery." 445 A.2d 606, 609 (D.C. 1982) (emphasis added) (citations omitted).

Florida. Kraft $v$. Mason: "[T] he few cases in Florida on this subject support the more modern-day approach that officious intermeddling is a necessary element of champerty. We define officious as 'offering unnecessary and unwanted advice or services . . . " 668 So. 2d 679, 682 (Fla. Dist. Ct. App. 1996) (citation omitted).

Georgia. Georgia Code Annotated: "Contracts of maintenance or champerty" are unenforceable as contrary to the public policy of Georgia. GA. CODE ANN. § 13-8-2(a) (5) (1982 \& Supp. 2001).

Hawaii. Van Gieson v. Magoon: In 1910, the Hawaii Supreme Court enforced a contract which "appears to be of a champertous nature" because "[t]he conditions of society under which the law of maintenance and champerty originated no longer exist." 20 Haw. $146,148-49$ (1910). 
Idaho. Wolford $v$. Tankersley: "While Idaho law does not recognize champerty and maintenance ... the goals of champerty and maintenance provisions are still around and well, both defensively and offensively, in the form of actions or defenses based on abuse of process or malicious prosecution of civil actions." 695 P.2d 1201, 1222 (Idaho 1984).

Illinois. Puckett v. Empire Stove Co.: "Champerty and maintenance have been disapproved by the courts as against public policy because a litigious person could harass and annoy others if allowed to purchase claims for pain and suffering and pursue the claims in court as an assignee." 539 N.E.2d 420, 427 (Ill. App. Ct. 1989).

Indiana. Reichhart $v$. City of New Haven: Indiana defines champerty and maintenance as "the aiding of a litigant by a stranger having no interest, direct or remote, immediate or contingent on agreement with the party in interest, whereby the stranger is to receive a part of the thing in dispute." 674 N.E.2d 27, 32 n.3 (Ind. Ct. App. 1996) (citation omitted).

Iowa. Ontjes v. McNider: The Iowa Supreme Court reiterated the holding of a previous court that "a contract of an attorney that produced champerty and maintenance would be declared void as against public policy." 12 N.W.2d 284, 292 (Iowa 1943) (citing Boardman \& Brown v. Thompson, 25 Iowa 487 (1868)).

Kansas. Boettcher v. Criscione: "[C]ommon barratry and champerty have been ... generally defined as ... frequently exciting and stirring up quarrels either at law or otherwise. Whether champerty and barratry is in violation of public policy ... turns largely on the facts and circumstances of each case." 299 P.2d 806, 811 (Kan. 1956).

Kentucky. Kentucky Revised Statutes Annotated: Kentucky law renders void "[a]ny contract, agreement or conveyance made in consideration of services to be rendered in the prosecution or defense, ... by any person not a party on record in the suit, whereby the thing sued for or in controversy ... is to be taken, paid or received for such services or assistance.” KY. REV. STAT. ANN. § 372.060 (Michie 1996).

Louisiana. Balboa Insurance Co. v. Algernon Blair, Inc.: "Out of a rich Louisiana gumbo [of state law], the [federal] District Court detected the bitterness of the ancient doctrine of champerty and dismissed the plaintiff's case as violative of public policy. We have subjected the identical recipe to our appellate palate and have found the concoction to be both savory and nutritious." 795 F.2d 404, 405 (5th Cir. 1986).

Maine. Maine Revised Statutes Annotated: "A person is guilty of 
champerty if, with the intent to collect by a civil action a claim, account, note or other demand due, or to become due to another person, he gives or promises anything of value to such person." ME. REV. STAT. ANN. tit. 17-A, $\$ 516(1)$ (West 1983). In Maine, champerty is a Class E crime, id. $\S 516(3)$, warranting a fine of up to $\$ 1000$, id. $\S$ 1301 (1) (E), or imprisonment of up to 6 months, id. $\$ 1252(2)(\mathrm{E})$.

Maryland. Hernandez $v$. Suburban Hospital Ass' $n$ : Maryland allows for the prejudgment assignment of personal injury awards to health care providers to secure incurred medical expenses. 572 A.2d 144, 148 (Md. 1990).

Massachusetts. Saladini $v$. Righellis: Massachusetts no longer recognizes champerty as an offense. But this "ruling today should not be interpreted to indicate our authorization of the syndication of lawsuits." 687 N.E.2d 1224, 1228 n.7 (Mass. 1997).

Michigan. Smith v. Childs: "[T]he [contract] defense of champerty does not exist in Michigan except as specified by statute with regard to attorneys." 497 N.W.2d 538, 540 (Mich. Ct. App. 1993).

Minnesota. Huber $v$. Johnson: "We do not think that any court . . has ever gone so far as to hold that contracts may not so manifestly tend to stir up strife . . . and speculative litigation, and prevent the amicable compromise of claims between citizens, as to be void on grounds of public policy." 70 N.W. 806, 807-08 (Minn. 1897).

Mississippi. Mississippi Code Annotated: Under Mississippi law, it is unlawful for any person "either before or after proceedings commenced: (a) to promise, give, or offer, (b) to receive or accept . . . , (c) to solicit, request, or donate, any money . . . or any other thing of value, or any other assistance as an inducement to any person to commence or to prosecute further ... any proceeding in any court," but this provision does not infringe on the constitutional right "of regular employment of any attorney at law or solicitor in chancery, for either a fixed fee or upon a contingent basis, to represent such person." MISS. CODE ANN. $§ 97-9-11$ (1999). "Any person violating any of the provisions of section 97-9-11 shall be guilty of maintenance and, upon conviction thereof, shall be punished by imprisonment for one year in the state penitentiary." Id. $\$ 97-9-13$.

Sneed v. Ford Motor Co.: "Mississippi has declared champerty and maintenance unlawful." 735 So. 2d 306, 309 (Miss. 1999).

Missouri. Macke Laundry Service Ltd. Partnership v. Jetz Service Co.: Actions of champerty and maintenance of litigation "are rare in modern times, having been replaced by the causes of action of abuse of process, wrongful initiation of litigation and malicious prosecution" 
but "have been found to be in force in this state by the Missouri Supreme Court." 931 S.W.2d 166, 171 n.1 (Mo. Ct. App. 1996) (citations omitted).

Montana. Montana Code Annotated: "An attorney and counselor must not . . promise or give . . . a valuable consideration to any person as an inducement to placing or in consideration of having placed in his hands or in the hands of another person a demand of any kind for the purpose of bringing an action thereon." MONT. CODE ANN. $\$ 37-61-408(2)(2001)$. "[Section 37-61-408(2) applies] to a person prosecuting an action in person who does an act which an attorney and counselor is therein forbidden to do." Id. § 37-61-411 (2001).

Green $v$. Gremaux: "Today, the common law prohibition of champerty is codified at $\S 37-61-408$ [of the Montana Code Annotated]." 945 P.2d 903, 907 (Mont. 1997).

Lussy v. Bennett: The Montana Supreme Court voided a contract as violative of $\S 37-61-411$, asserting that a suit to enforce its provisions "smacks of champerty, and public policy requires dismissal of [the] action." 692 P.2d 1232, 1235-36 (Mont. 1984).

Nebraska. Omaha $\mathcal{E}$ Republican Valley Railway Co. v. Brady: "Champerty is not a criminal offense, nor is a champertous contract illegal under our statutes; and if this contract is champertous and voidable, it is because it is contrary to public policy to enforce it." 57 N.W. 767, 772 (Neb. 1894).

Nevada. Schwartz $v$. Eliades: "To maintain the suit of another is now, and always has been, held to be unlawful, unless the person maintaining has some interest in the subject of the suit." 939 P.2d 1034, 1036 (Nev. 1997) (quoting Lum v. Stinnett, 488 P.2d 347, 350 (Nev. 1971)). Champerty is a species of maintenance hinging on the absence of an interested party.

New Hampshire. Adkin Plumbing $\mathcal{F}^{\circ}$ Heating Supply Co. v. Harwell: "[We have] noted the changing attitude toward contracts in champerty and determined that such contracts no longer constituted a violation of public policy." 606 A.2d 802, 803-04 (N.H. 1992).

Markarian v. Bartis: "It is our conclusion that, except in those cases where it is found as a fact that litigious strife is sought to be promoted, the rule against champerty and maintenance is not now in force in this jurisdiction." 199 A. 573,577 (N.H. 1938).

New Jersey. Polo v. Gotchel: "This Court need not address the doctrines of champerty and maintenance, as they do not presently exist in New Jersey." 542 A.2d 947, 949 (N.J. Super. Ct. Law Div. 1987) (citation omitted). 
New Mexico. Reinhardt $v$. Kelly: The New Mexico Court of Appeals overturned, on the facts, a trial court ruling that "declared an agreement between the Plaintiff and [a third party] to file the suit as champertous and thus void as against public policy." 917 P.2d 963, 963-64 (N.M. Ct. App. 1996).

New York. New York Judiciary Law: New York law curtails the purchase of any "bond, promissory note, bill of exchange, book debt, or other thing in action, or any claim or demand, with the intent and for the purpose of bringing an action or proceeding thereon." N.Y. JuD. LAW $\$ 489$ (McKinney 1983).

Bluebird Partners, L.P. v. First Fidelity Bank: "Champerty is a venerable doctrine developed hundreds of years ago to prevent or curtail the commercialization of or trading in litigation. It is currently codified in New York as Judiciary Law $§$ 489." 731 N.E.2d 581, 582 (N.Y. 2000).

Coopers $\mathcal{E}^{\circ}$ Lybrand v. Levitt: "The doctrine of champerty does not prevail in this State except as provided by statute." 384 N.Y.S.2d 804, 807 (App. Div. 1976) (citations omitted).

Grossman v. Schlosser: While personal injury tort claims are not assignable under N.Y. GEN. OBLIG. LAW § 13-101 (McKinney Supp. 2001), "the assignment of the proceeds of such a cause of action, prior to its settlement or adjudication, [is] valid and effectual as an equitable assignment against the assignor and his attaching creditor, and ... such an assignment [is] not against public policy." 244 N.Y.S.2d 749, 750-51 (App. Div. 1963).

North Carolina. Charlotte-Mecklenburg Hospital Authority v. First of Georgia Insurance Co.: "The assignment of a claim gives the assignee control of the claim and promotes champerty. Such a contract is against public policy. The assignment of the proceeds of a claim does not give the assignee control of the case and there is no reason it should not be valid." 455 S.E.2d 655, 657 (N.C. 1995) (citation omitted).

North Dakota. Interstate Collection Agency $v$. Kuntz: "While the authorities differ as to all the ingredients essential to constitute champerty, they seem agreed that the gist of the offense is the malicious or officious intermeddling in a suit in which the intermeddler has no interest." 181 N.W.2d 234, 242 (N.D. 1970) (quoting Rohan v. Johnson, 156 N.W. 936,937 (N.D. 1916)).

Ohio. Tosi $v$. Jones: “[T] he doctrines of champerty and maintenance appear in numerous Ohio cases as contract defenses. Ohio has never recognized a common law tort for champerty and mainte- 
nance." 685 N.E.2d 580, 583 (Ohio Ct. App. 1996) (citations omitted).

Oklahoma. Mitchell v. Amerada Hess Corp.: "The proof necessary to demonstrate the contract to lease for oil and gas was champertous must establish both officious intermeddling and lack of an interest in the action apart from the alleged champertous document." $638 \mathrm{P} .2 \mathrm{~d}$ 441, 444 (Okla. 1981).

Oregon. Brown $v$. Bigne: "The doctrine of champerty . . . ought not to prevail when such aid is furnished by a layman; but when such contracts are made for the purpose of stirring up strife and ... inducing suits to be begun which otherwise would not ... they come within ... that doctrine, and should not be enforced." 28 P. 11, 13 (Or. 1891).

Pennsylvania. Clark v. Cambria County Board of Assessment Appeals: "[C]hamperty has long been considered repugnant to public policy against profiteering and speculating in litigation and grounds for denying the aid of the court. The common law doctrine against champerty and maintenance continues to be a viable doctrine in Pennsylvania and can be raised as a defense." 747 A.2d 1242, 1245-46 (Pa. Commw. Ct. 2000) (citations omitted).

Rhode Island. Martin $v$. Clarke: "Whether we look, therefore, at the ancient common law, to the English statutes upon the subject, or to our own legislation, the conclusion must be the same,--that champerty is an offence against the law. Being such, it must avoid every contract into which it enters." 8 R.I. 389, 403 (1866).

South Carolina. Osprey, Inc. v. Cabana Ltd. Partnership: "[W]e abolish champerty as a defense. We are convinced that other welldeveloped principles of law can more effectively accomplish the goals of preventing speculation in groundless lawsuits ... than dated notions of champerty." 532 S.E.2d 269, 277 (S.C. 2000).

South Dakota. McKellips v. Mackintosh: "There [has been] no statutory or judicial repudiation of the common law remedy of champerty; therefore, this court must hold that the doctrines of champerty and maintenance currently apply in South Dakota." 475 N.W.2d 926, 929 (S.D. 1991).

Tennessee. Record v. Insurance Co. of North America: "[I]n 1899 the Champerty Statutes of this State were repealed to leave in effect only that portion of the laws which relates to the effect of the conveyance of land adversely held." 438 S.W.2d 743, 747 (Tenn. 1969).

Can Do Inc. $v$. Mainer: The Tennessee Supreme Court voided a contract assigning legal malpractice claims, in part because such as- 
signments promote champerty. 922 S.W.2d 865, 869 (Tenn. 1996).

Texas. Baker $v$. Mallios: A Texas court adopted North Carolina's position that assignments of chose in action are more problematic than mere assignments of future judgment. 971 S.W.2d 581, 587 (Tex. App. 1998).

Utah. Croco v. Oregon Short Line Railroad Co.: The Utah Supreme Court held that the common law of champerty and maintenance, as modified by statute in the case of attorneys and clients, is a contract defense that must be plead or lost. 54 P. 985, 987-88 (Utah 1898).

Vermont. D'Amato v. Donatoni: In the most recent champerty case heard by the Vermont Supreme Court, that court found an attorney's contingency fee contract not to be champertous. The Court cited Hamilton v. Gray, 31 A. 315, 316 (Vt. 1894), for the propositions that "[a] champertous agreement was void at common law, and we think the common law as to champerty is in force in this state." 168 A. 564, 568 (Vt. 1933).

Virginia. Virginia Code Annotated: "Only those causes of action for damage to real or personal property, ... and causes of action $e x$ contractu are assignable. . . [T] his section shall not prohibit any injured party or his estate fram making a voluntary assignment of the proceeds or anticipated proceeds of any court award or settlement ..." VA. CODE ANN. § 8.01-26 (Michie 2000).

In re Musser: "[T] he prohibition against assignments of causes of action for personal injury does not proscribe a hospital from obtaining an equitable assignment of the sums to be recovered by an individual from a tortfeasor to the extent of the value of the services provided by the hospital." 24 B.R. 913, 922 (W.D. Va. 1982).

Washington. Giambattista v. National Bank of Commerce: "It is questionable whether many remnants of these doctrines [champerty and maintenance] remain in this state." 586 P.2d 1180, 1186 (Wash. Ct. App. 1978).

West Virginia. Currence v. Ralphsnyder: The West Virginia Supreme Court of Appeals recognized that the circumstances which necessitated champerty no longer exist, and the court refused to "nullify the contract merely because it savors of champerty under the common law." 151 S.E. 700, 702 (W. Va. 1929).

Wisconsin. Wisconsin Statutes Annotated: "No action, special proceeding, cross complaint or counterclaim in any court shall be dismissed on the ground that a party to the action is a party to a contract savoring of champerty or maintenance unless the contract is the basis of the claim pleaded." WIS. STAT. ANN. $\$ 895.375$ (West 1997). 
Wyoming. Johnson v. Sellers: The Wyoming Supreme Court heard a claim that the purchase of land with the intent to bring suit should be voided as champerty. 84 P.2d 744, 745 (Wyo. 1938). The court, however, has never directly ruled on the enforceability of a champertous contract formed between a plaintiff and a champertor other than the plaintiff's lawyer. 
